Working Paper/Document de travail 2011-26

\title{
Security Transaction Taxes and Market Quality
}

by Anna Pomeranets and Daniel G. Weaver 
Bank of Canada Working Paper 2011-26

November 2011

\title{
Security Transaction Taxes and Market Quality
}

by

Anna Pomeranets ${ }^{1}$ and Daniel G. Weaver ${ }^{2}$

\author{
${ }^{1}$ Financial Markets Department \\ Bank of Canada \\ Ottawa, Ontario, Canada K1A 0G9 \\ apomeranets@bankofcanada.ca \\ 2Department of Finance and Economics \\ Rutgers Business School \\ Rutgers University \\ Piscataway, New Jersey 08854-8054 \\ daniel_weaver@rbsmail.rutgers.edu
}

Anna Pomeranets is the author to whom correspondence should be addressed.

Bank of Canada working papers are theoretical or empirical works-in-progress on subjects in economics and finance. The views expressed in this paper are those of the authors.

No responsibility for them should be attributed to the Bank of Canada. 


\section{Acknowledgements}

We thank Yakov Amihud, Sermin Gungor, Scott Hendry, Charles Jones, Simi Kedia, Teodora Paligorova, Oded Palmon, Joshua Slive, Gwendolyn Webb, and Jonathan Witmer for their comments on earlier versions of this study. We thank the Whitcomb Center for Research in Financial Services for research support. 


\begin{abstract}
We examine nine changes in the New York State Security Transaction Taxes (STT) between 1932 and 1981. We find that imposing or increasing an STT results in wider bidask spreads, lower volume, and increased price impact of trades. In contrast to theories of STT imposition as a means to reduce volatility, we find no consistent relationship between the level of an STT and volatility. We examine the propensity of traders to switch trading locations to avoid the tax and find no consistent evidence that they will change locations. We do find evidence to suggest that taxes imposed on the par value of stock will result in corporations managing the par value in the direction of minimizing the impact of the tax on investors.

JEL classification: G10, G12, C43

Bank classification: Financial markets; Market structure and pricing; Econometric and statistical methods
\end{abstract}

\title{
Résumé
}

Les auteurs examinent les neuf changements que l'État de New York a apportés à sa taxe sur les transactions de titres entre 1932 et 1981. Ils constatent que l'instauration d'une taxe de ce genre ou sa majoration conduit à un élargissement des écarts entre les cours acheteur et vendeur, à une baisse des volumes ainsi qu'à une augmentation de l'incidence des transactions sur les prix. À l'inverse de ce que prédisent les théories prônant l'imposition d'une taxe sur les transactions afin de réduire la volatilité des marchés financiers, ils n'observent aucun lien systématique entre le niveau de la taxe et celui de la volatilité. Ils se penchent aussi sur la tendance qu'auraient les arbitragistes à se relocaliser pour soustraire leurs transactions à la taxe. Les données ne corroborent pas cette hypothèse. Les auteurs relèvent cependant des indices montrant que l'imposition d'une taxe sur la valeur nominale d'une action incite la société émettrice à gérer cette valeur de manière à minimiser l'effet de la taxe sur les investisseurs.

Classification JEL : G10, G12, C43

Classification de la Banque : Marchés financiers; Structure de marché et fixation des prix; Méthodes économétriques et statistiques 
Securities transaction taxes (STTs) have received renewed interest as a result of the recent economic turmoil. At the Pittsburgh summit in September 2009, the G-20 leaders tasked the International Monetary Fund (IMF) to explore a "range of options countries have adopted or are considering as to how the financial sector could make a fair and substantial contribution toward paying for any burdens associated with government interventions to repair the banking system" and report back for the June 2010 Toronto meeting. An STT was one potential instrument considered for raising revenue from the sector's activities and has gained support from several G-20 countries, such as France and Germany. ${ }^{1}$

For decades advocates of STTs have argued that the tax can be used to raise significant tax revenue while discouraging destabilizing speculative trading and limiting excess volatility by 'throw[ing] sand in the wheels' of financial markets. Opponents of STTs, in contrast, argue that an STT will harm market quality by reducing volume, increasing price volatility and causing inefficient price discovery. They contend that an STT can lead to lower asset prices, an increased cost of capital for businesses, lower returns to savings and widespread tax evasion. This debate is frequently revisited, yet no consensus on the impact of STTs has been reached. The issue though has immediate policy implications, and is of great interest to policymakers, academics and politicians.

Empirical studies examining the implications of an STT either use a quasi-tax ${ }^{2}$, test smaller markets which do not provide a variety of firm sizes, or look at international market competition where a lack of fungibility inhibits the transfer of volume from one exchange to another. Further, there is no existing empirical study of the impact of a U.S. imposed STT on

\footnotetext{
1 "Germany, France Press EU on Transaction Tax" Wall Street Journal, July 9, 2011.

${ }^{2} \mathrm{~A}$ quasi-tax is a fixed financial payment required to trade (e.g. fixed commissions).
} 
market quality. ${ }^{3}$ Nor is there an empirical study that examines the direct impact of a security transaction tax on equity spreads. This paper strives to fill that void by examining nine changes in the level of an STT imposed by New York State from 1905 to 1981 . This is the first paper to comprehensively examine the impact of a U.S. imposed STT on various measures of market quality. In addition, unlike previous studies that observe the transfer of volume across country borders, our dataset offers the opportunity to test the hypothesis that an STT in New York State shifts volume from the NYSE to U.S. regional exchanges.

While proponents of STTs argue that the imposition or increase in the tax will reduce speculative trading and thus volatility, we find no significant relationship between an STT and volatility. Being the first paper to empirically examine the impact an STT has on spreads, we find that an increase in the level of the STT is accompanied by an increase in spreads. Consistent with previous literature we find that volume moves in the opposite direction of the tax change. Finally, we find a direct relationship between STTs and price impact. Taken together we find that an STT harms market quality.

In the following section, we review the regulatory history of U.S. STTs at both the state and federal level. We then review existing theoretical and empirical work in section III. Section IV describes our data and presents our methodology, Section $\mathrm{V}$ contains results and is followed by our conclusions in section VI.

\section{Regulatory History}

The first New York State transfer tax was imposed on June 1, 1905 at the rate of two cents per $\$ 100$ of par value on stocks traded, transferred, or delivered in New York State. ${ }^{4}$ The tax was not implemented as a financial stability measure, but a revenue generator and was

\footnotetext{
${ }^{3}$ Amihud and Mendelson (1992) argue that a STT of 0.5 percent will increase transaction costs. Employing a model of asset pricing with transaction costs they project that a 0.5 percent STT will increase the average firm cost of capital by 1.3 percent and reduce the average NYSE stock price by 13.8 percent. ${ }^{4}$ Traded refers to the location of the exchange or contra broker. Transferred refers to the location of the transfer agent. Delivered refers to the domicile of the stock's seller.
} 
estimated to produce annual revenues of $\$ 5,000,000$ to make up for the state deficit. $^{5}$ The original law contained a graduated tax schedule for stocks with par values below $\$ 100$. In 1906 , the New York legislature passed an amendment to the law which eliminated the graduated schedule for stocks with par values less than $\$ 100$. In January of 1907 that amendment was declared unconstitutional and the graduated schedule was reinstated. Seven years later in response to some companies issuing stock with no par value, the law was amended to place a two cent tax on shares issued without par value. ${ }^{6}$ Suffering under the weight of the Great Depression, New York doubled the STT on March 1, 1932 to four cents per $\$ 100$ of par value and four cents per share for stocks without a par value to meet large state deficits. The graduated feature of the tax was effectively maintained for stocks with par values less than $\$ 100$ per share. For example, a stock with a par value of $\$ 10$ paid an STT of $\$ 0.004$ per share.

In an effort to avoid the now doubled STT, firms began reducing their par values. By March of 1933200 listed firms had reduced their par values to between $\$ 1$ and $\$ 10$ thereby greatly reducing the impact of the tax. ${ }^{7}$ In response to this trend, New York's governor proposed that the tax be changed to a price basis rather than par value. ${ }^{8}$ Effective June 2, 1933 the tax became $\$ 0.03$ per share for stocks trading below $\$ 20$ a share and $\$ 0.04$ per share for stocks trading at or above $\$ 20$.

In 1945 the schedule was modified for shares selling for less than $\$ 20$. In particular, for shares selling for less than $\$ 5$, a tax of $\$ 0.01$ per share was charged; for shares selling between $\$ 5-10$ a tax of $\$ 0.02$ per share was charged; for shares selling between $\$ 10-20$ a tax of $\$ 0.03$ per share was charged; and for shares selling for over $\$ 20$ a tax of $\$ 0.04$ was charged. ${ }^{9}$ This tax schedule remained in effect for 21 years, when on July 1, 1966 the STT was increased by $25 \%$.

\footnotetext{
5 "The Stock Transfer Tax", New York Times, 14 March 1905.

6 "Stock Transfer Tax Amendment," Wall Street Journal, Jun 4, 1913, p. 7.

7 "Brokers Assail Stock Tax Plan," New York Times, Mar 26, 1933, p. N8.

${ }^{8}$ Ibid

9 “Transfer Tax Bill Signed", New York Times, 20 April 1945.
} 
Following the 1966 STT increase, the New York Stock Exchange (NYSE) began lobbying New York State to reduce the tax stating that it put them at a competitive disadvantage relative to out-of-state exchanges. As it had done in the past the NYSE threatened to move out of New York to avoid the tax. Bowing to pressure from the NYSE, in 1968, an amendment was introduced that gradually reduced the tax imposed on non-residents until it reached a reduction of $50 \%$ by July $1,1973 .{ }^{10}$ At the time, $12 \%$ of US investors were subject to the tax as New York residents. ${ }^{11}$ The amendment also capped the maximum tax liability per trade for residents and non-residents placing orders within New York to $\$ 350 .^{12}$

In August 1975, a 25\% surcharge was imposed on all stock transactions, which would expire on July 31, 1978. Prior to its expiration, in a lawsuit filed by the Boston Stock Exchange, the U.S. Supreme Court found the 1968 amendments to be unconstitutional because they violated the interstate commerce clause by discriminating against interstate sales. ${ }^{13}$ New York taxed sales made on non-New York exchanges more heavily than those sales made on New York exchanges. As a result, following the $25 \%$ surcharge expiration on July 31 , 1978, a four year phase-out period began. During this period, rebates were issued to residents, nonresidents and orders placed through the Inter-market Trading System (ITS). ${ }^{14}$ For New York residents, starting October $1,1979,100 \%$ of the tax was paid and $30 \%$ was rebated; beginning October 1, 1980, 60\% was rebated; and starting October 1, $1981100 \%$ was rebated. The phase-out period was slightly different for non-residents who continued to pay $50 \%$ of the tax through July 31, 1978 and from August 1, 1978 to September 30, 1980, paid 62.5\%. This

\footnotetext{
10 "Stock-Transfer Tax Cut Is Signed," New York Times, 23 June 1968, p.44.

${ }^{11}$ lbid

12 Between July 1, 1969 to June 30, 1970 non-residents paid 95\%; July 1, 1970 to June 30, 1971 nonresidents paid $90 \%$; July 1, 1971 to June 30,1972 non-residents paid $80 \%$; July 1, 1972 to June 30 , 1973 non-residents paid $65 \%$ and starting on July 1, 1973 and thereafter non-residents paid $50 \%$.

${ }^{13}$ U.S Supreme Court. Boston Stock Exchange v. State Tax Commission, 429 U.S. 318 (1977)

14 The inter-market trading system is an electronic linkage system that links together U.S. equity exchanges and $100 \%$ of the tax was rebated on all orders placed through ITS so that the tax would not hinder market competition. As a result, non-residents could avoid the tax entirely by placing orders through ITS.
} 
coincided with the expiration of the $25 \%$ surcharge and left the effective tax paid by nonresidents unchanged. Starting October 1, 1980 non-residents were subject to the same tax schedule as residents. Appendix A illustrates effective transfer tax rates for various stock prices and partitioned by whether the investor was a New York resident or not.

New York was not the only taxing authority to levy transfer taxes. On December 1, 1914, the federal government imposed a $\$ 0.02$ tax on each $\$ 100$ of par value of stock to help pay for the cost of US involvement in World War I. That tax was repealed briefly in September of 1916, but reinstated in December $1917 . .^{15}$ On June 21,1932 the tax was changed to $\$ 0.04$ per $\$ 100$ of par value, unless the stock was trading above $\$ 20$ in which case it was $\$ 0.05$ per $\$ 100$ of par value. Stocks without par values were taxed on a per share basis. On September 20, 1941, the tax was increased to $\$ 0.05$ (\$0.06) per $\$ 100$ of par value for stocks trading at or below (above) $\$ 20$ per share. The federal tax was repealed in January 1966.

Massachusetts and Pennsylvania also levied transfer taxes at one time, but their impact was much smaller than the New York tax. By 1939 Massachusetts and Pennsylvania levied a tax of two cents per $\$ 100$ of aggregate par-value of stock sold or two cents per share in the case of no par-value stock. ${ }^{16}$ The fact that New York levied the tax on a per share basis and Massachusetts and Pennsylvania used aggregate par value resulted in a much higher tax paid in New York. For example, assume a trade involving 100 shares of a $\$ 10$ par value stock for $\$ 40$ a share. The New York tax is $\$ 4$ (\$0.04 on each share sold) while the Pennsylvania and Massachusetts tax is $\$ 0.20$, since the aggregate par-value of the 100 shares is $\$ 1,000$. It can therefore be seen that the New York tax is 20 times greater than the tax in Massachusetts or Pennsylvania. ${ }^{17}$ We could find no record of any other state imposing a transfer tax other than New York, Massachusetts, and Pennsylvania.

\footnotetext{
15 "Wall St. Sees End of Stock Sales Tax", New York Times, 4 July 1916.

${ }^{16}$ Recall that New York switched to taxing on a per share basis much earlier,

17 "Stock-Deal Taxes and Their Effects", New York Times, 10 December 1939. Both the MA and PA transaction taxes remained inconsequential and were repealed in the 1950s.
} 
Corporations could reduce the impact of the tax on their shareholders, by managing their par values. To investigate this possibility, we obtain par values for our sample of 236 stocks from the 1932 doubling of the New York tax from the Moody's Manuals for $1934 .{ }^{18}$ We find that railroad industry stocks tend to have par values of $\$ 100$ (20 out of 27 firms). For the 200 nonrailroad industry stocks covered by Moody's, there were only ten with par values of $\$ 100$, while 132 listed no par value and 58 had par values between $\$ 1$ and $\$ 50$. We also examine reported changes in par value around the 1932 New York doubling of their STT. We find that 28 firms (from our sample of 236) changed their par value between 1930 and 1933. Of these 28 we find that 24 changed to a par value that lowered taxes based on par. ${ }^{19}$ Therefore we conclude that firms actively changed their par values to avoid STTs for their investors. Thus, STTs that are based on share price cannot be avoided by corporate actions and will have the largest impact on investors. We would then expect the New York STT to have a measurable impact on investor behaviour and hence market quality.

One purpose of this study is to examine the change in market share across state lines around transaction tax changes. Since the federal transfer tax could not be avoided inside the United States and states other than New York imposed a minuscule tax, we focus on those tax changes occurring in New York. We are however cognisant of confounding impacts so we are careful to control for changes in federal tax rates around the time of New York tax changes.

\section{Literature Review}

Theoretical papers have not reached a consensus on the impact of STTs on market quality. Some argue that an STT will improve market quality, while others argue that it will

\footnotetext{
${ }^{18}$ See Moody's Manual of Investments and Security Rating Service volumes for industrial, bank and financial, public utility, and railroad securities.

${ }^{19}$ Fifteen increased their par value from zero to a small positive number and nine reduced their par to a smaller number. The remaining four firms reduced their par value to zero.
} 
reduce it. Still others state that the effect is ambiguous. Following is a review of the different camps in this ongoing debate.

The earliest proponents of STTs, Keynes (1936) and Tobin (1978), argue that an STT will improve market quality. In particular, Keynes contends that chasing short-term returns, while potentially profitable to specific individuals, is a zero-sum game in terms of economic welfare. Since one investor's gain is another's loss and trading utilizes resources, the value-added through trading is negative. As a result, imposing an STT may increase welfare by reducing wasted resources. Second, since trading is speculative by nature, it potentially contributes to financial instability when trades are driven by short-term capital gains and not fundamental information. Keynes argues that an STT will curtail short-term speculation, and thereby reduce wasted resources, market volatility and asset mispricing. Consistent with Keynes, Tobin (1978) proposes a tax on foreign exchange transactions that would make short term currency trading unprofitable. He suggests that a transaction tax would "throw some sand in the wheels of speculation."

Consistent with Keynes (1936) and Tobin (1978), Stiglitz (1989) and Summers and Summers (1989) argue that an STT targets short-term noise traders whose trades contribute to excess market volatility. Therefore, an STT results in a reduction in volatility.

Stiglitz (1989) further argues that the impact of an STT on market liquidity would be insignificant by examining the inventory risk component of the bid-ask spread. He contends that although an STT will lead to thinner markets, the change in spread will be insignificant since the extra time that market-makers hold securities will not yield a significant change in the inventory risk component of the spread.

In stark contrast to the proponents of an STT, the opponents argue that an STT will have an adverse impact on market quality. In particular, Kupiec (1996) develops a model where an STT is directly related to excess volatility. Similarly, Amihud and Mendelson (2003) conclude 
that an STT is directly related to volatility since STTs reduce the amount of informed trading, thereby widening the gap between the transaction prices and the security's fundamental value.

Schwert and Seguin (1993) argue that an STT would indirectly increase transaction costs through the three components of the bid-ask spread: order processing costs, inventory risk and information asymmetry. ${ }^{20}$ For example, since an STT reduces trading volume, the number of trades available for the market-maker to recover his fixed cost declines, thereby increasing the order processing component of the spread. ${ }^{21}$ The authors further theorize that an increase in spreads results in an increase in the cost to traders who take advantage of securities mispricing, and thus reduces market efficiency. That is, when transaction costs increase, larger and more persistent mispricing is likely. With regards to volatility Schwert and Seguin suggest that there is no evidence of excess volatility and since the tax is a burden on all traders, the reduction in trading will not limit the activity of noise traders alone-it will affect liquidity traders and price-stabilizing informed traders as well. Therefore, the impact of the tax on volatility is ambiguous.

Just as the theoretical literature is divided on the impact of STTs on market quality, so too is the empirical literature. Apart from Roll (1989), which performs cross-country regressions, the eleven empirical studies examine 28 different STT tax (and quasi-tax) changes in 11 different countries. We summarize the empirical literature in Table 1 and discuss it below. For each paper we list the change in percentage tax (quasi-tax) for each event since there may be a relationship between the size of the change and the impact on volatility. We also list for each paper the measures examined in the paper as well as the finding for each measure. Statistically

${ }^{20}$ The order processing component is part of the fixed cost the market-maker charges for trade execution. The inventory risk component is the market-maker's compensation for holding onto risky assets. The information asymmetry component represents the likelihood that a market-maker is facing an informed trader who has superior knowledge of the asset's fundamental value.

${ }^{21}$ An STT will also increase the order processing component directly due to the cost of collecting the tax. Second, because equity market-makers use derivatives to hedge their risky inventory positions, an STT on derivatives increases the cost of hedging their positions. The increase in the market-maker's cost for hedging increases the inventory risk part of the bid-ask spread. Finally, if an STT reduces the amount of noise trading, as proponents suggest, then the possibility of the market-maker facing an informed trader increases, thereby increasing the information asymmetry element of the bid-ask spread. 
significant findings are indicated by an asterisk, otherwise the finding is insignificant. Rather than discussing each paper separately we will focus on the findings for each measure of market quality examined.

\section{Volatility}

Of the nine papers that empirically examine changes in volatility around changes in STTs, only one (Roll (1989)) finds the inverse relationship predicted by Stiglitz (1989) and Summers and Summers (1989). That relationship is, however not significant. Two of the papers (Baltagi, Li, and Li (2006) and Jones and Seguin (1997)) find a statistically significant direct relationship between volatility and the level of an STT which supports the predictions of Kupiec (1996) and Amihud and Mendelson (2003). The remaining papers either find an insignificant direct relationship (Umlauf (1993) and Hau (2006)) or conclude that they find no relationship.

\section{Volume}

Each of the five studies that examine the relationship between volume and an STT find evidence of an inverse relationship. Baltagi, Li, and Li (2006) find a statistically significant relationship while the remaining papers (Hu (1998), Liu (2007) Sahu (2008) and Jarrell (1984)) report an insignificant inverse relationship. ${ }^{22}$ These papers support the theoretical predictions of an inverse relationship argued by Schwert and Seguin (1993). A complementary measure related to volume used in the literature is market share. For example, Campbell and Froot (1994) point out that in many cases domestic investors can avoid STTs by trading in another country. Consistent with Campbell and Froot, Umlauf (1993), finds that an increase in a securities transaction tax results in a decline in market share in the domestic country. Existing studies may not be able to capture the true level of volume transferred between exchanges due to currency risk concerns as well as the lack of fungibility existing across borders.

\section{Spreads}

22 Jarrell (1984) does not conduct tests of significance. 
Prior to this study there has been a lack of empirical evidence of the impact of an STT on spread. The literature on the impact of stock transaction taxes on spreads largely relies on the indirect effect of trading volume on liquidity.

Bloomfield, O'Hara and Saar (2009) examine the relationship between spreads and STTs in a laboratory setting in the context of different types of traders. They examine three scenarios for the impact of an STT on the components of bid-ask spread. If noise traders are less active because of the STT, the inventory risk component of the spread may decrease; the adverse selection cost may increase; or it may remain unchanged. If noise traders trade less, then prices will be less volatile and the inventory risk component of the bid-ask spread will decline, thereby increasing liquidity. However, if noise traders trade less, increasing the probability of informed trading, then the adverse selection costs could increase, resulting in a increase in spreads. Finally, given a decline in noise trading from an STT, informed traders may trade less aggressively on their information, keeping adverse selection costs unchanged. Bloomfield, O'Hara and Saar (2006) use the total price impact as a proxy for spreads and find no significant effect on spreads or price impact.

The empirical literature does not reach a consensus. By empirically examining nine changes in the level of an STT in the same market with market share not being clouded by fungibility, this paper adds to the empirical literature on STTs.

\section{Data and Methodology}

We obtain dates for changes in the level of security transaction taxes at the state and federal level from the New York Times and Wall Street Journal. As stated earlier, in addition to the federal stock transfer tax instituted in 1914, the states of New York, Massachusetts, and Pennsylvania all enacted STTs during the last century. As previously shown, the Massachusetts and Pennsylvania taxes were minuscule so they are ignored. Since one goal of this paper is to examine whether traders move their trading to avoid taxes, we do not examine the nationwide 
federal tax. We then focus on changes in the New York STT from its imposition in 1905 through its elimination in 1981. The dates and tax rates are contained in Appendix A. There are eleven tax changes that impact both residents and non-residents. The October 1, 1968 tax change placed a cap of $\$ 350$ on the tax paid for one transaction. The cap impacted trades of over 7,000 shares for prices above $\$ 20$ and trades of over 28,000 shares for prices less than $\$ 5$. Since this was limited to larger trades we would not expect a market wide change in market quality and thus do not examine that change.

We use daily closing prices and volume to estimate the impact of an STT on volatility, spreads and price impact. Daily closing prices and volume for the NYSE, American Stock Exchange (AMEX) and National Association of Securities Dealers Automated Quotations (NASDAQ) are obtained from the Center for Research in Security Prices (CRSP). The CRSP databases do not contain prices prior to 1925; therefore due to data limitations we are not able to examine the imposition of the New York STT in 1905. We then limit our study to the nine remaining tax changes that impact both residents and non-residents.

Consistent with Jones and Seguin (1997), we define sample stocks as all those continuously traded on the two New York stock exchanges - the NYSE and AMEX from one year before to one year after each tax change. There are four exceptions to this rule due to the proximity of confounding events. The March 1932 New York increase occurs just three months before the June 1932 doubling of the federal STT. As stated earlier, corporations managed the STT paid by their investors by changing their par values. We hypothesize that changing the New York STT to a per share basis (June 1933) will have a larger impact on market quality than doubling the amount taxed on par value at both the New York (March 1932) and Federal (June 1932) level. To test this hypothesis we use the twelve months before the March 1932 New York event and the eleven months June 1932 through May 1933 as the post period. For the July 1966 New York state tax increase, six months pre and post are used to avoid a confounding influence related to the January 1966 elimination of the federal security transaction tax. 
Similarly, fixed commissions (a pseudo transaction tax) were abolished three months prior to the August 1975 STT increase. Therefore, the 1975 event uses three months pre and post. Finally, the August 1, 1978 tax change coincides with the introduction of the Intermarket Trading System. A pilot program of 11 stocks traded on the NYSE and Philadelphia Stock Exchange began in April 1978. Between August and November 1978 the program was expanded to include all inter-listed stocks on multiple regional exchanges. The 1978 tax change gives orders placed through ITS (and destined for the NYSE) a 100\% rebate. To avoid confounding influences of the ITS start up period, we define the post period for the 1978 tax change as December 1978 through June 1979.

In their study of the elimination of fixed commissions, Jones and Seguin (1997) employ NASDAQ stocks as a control sample. During the period of our study, NASDAQ's headquarters was in Washington, DC. Many of the stocks listed on NASDAQ were similarly headquartered outside of New York and therefore stock transfers took place outside of New York as well. Finally many NASDAQ traders were not residents of New York. For these reasons a large portion of the trading occurring on NASDAQ was not subject to the New York STT. Therefore, we adopt the methodology of Jones and Seguin and use NASDAQ firms as a control sample. ${ }^{23}$ Since CRSP data are not available for NASDAQ prior to 1972 , we can only employ this control sample for tax changes from 1975 on.

The market quality measure that has garnered the most attention in theoretical and empirical papers is volatility. Following Jones and Seguin (1997) we adopt a portfolio approach rather than examining individual securities. Jones and Seguin argue that the portfolio approach is superior to examining single stocks since most investors hold portfolios and measuring portfolios removes measure bias due to microstructure effects such as the bid-ask bounce. The portfolios consist of either all the NYSE/AMEX stocks or all of the NASDAQ stocks. Volatility is

\footnotetext{
${ }^{23}$ Consistent with Jones and Seguin (1997) any NASDAQ stock with a market value less than the
} smallest NYSE/AMEX firm is excluded. 
defined as the standard deviation of continuously compounded daily returns for the period before $\left(\sigma_{\text {pre }}\right)$ and the period after $\left(\sigma_{\text {post }}\right)$ a change in the level of STT. We then specify the change in volatility as $\Delta \sigma=\sigma_{\text {post }}-\sigma_{\text {pre }}$. For each day t over the estimation period we calculate the equally weighted return for portfolio $\mathrm{p}$ (NYSE/AMEX or NASDAQ), $R_{p t}$. To estimate $\sigma_{\text {pre }}$ and $\sigma_{\text {post }}$ we follow Johnson and Kotz (1970) (as well as Jones and Seguin (1997)) and estimate the standard deviation of each portfolio $p$ by multiplying the mean absolute value of returns by $\sqrt{\frac{\pi}{2}}$, where $\pi$ is the mathematical constant. ${ }^{24}$

Table 2 reports cross-sectional means of market values, stock prices, and our daily return standard deviation measure of volatility based on continuously compounded returns for NYSE/AMEX and NASDAQ stocks for each tax change. For NYSE/AMEX stocks we observe that the average price is fairly stable over the entire sample period. We also note that volatility is fairly stable around each NYSE/AMEX STT change from 1945 on. For the NASDAQ stocks we observe that the firms are smaller than NYSE/AMEX firms and exhibit lower average prices than those of the NYSE/AMEX. Note that our sample of NASDAQ stocks has lower average volatility than the NYSE/AMEX sample. This is consistent with the findings of Jones and Seguin (1997).

To obtain an estimate of the change in volatility following a tax change, we regress the standard deviation of each portfolio on a dummy variable $I_{\text {Post,t }}$ which takes the value 1 if the day is after the tax change, otherwise zero or,

${ }^{24}$ Johnson and Kotz (1970) show that if returns are normally distributed, an unbiased estimator of $\sigma$ can be obtained by multiplying the mean deviation by $b_{n}=\sqrt{\frac{\pi}{2} n(n-1)^{-1}}$, where $\mathrm{n}$ is the number of observations. When $\mathrm{n}$ is large, $b_{n}=\sqrt{\frac{\pi}{2}}$. Under the assumption that the mean of asset returns is zero, the mean deviation reduces to $\left|R_{p t}\right|$. Johnson and Kotz (1970) note that an unbiased estimator of standard deviation is the mean deviation multiplied by $b_{n}$. It then follows that when the mean asset return is zero and $n$ is large, the standard deviation of portfolio $p$ is $\sqrt{\pi / 2}\left|R_{p t}\right|$. 


$$
\sqrt{\pi / 2}\left|R_{p t}\right|=\beta_{p 0}+\beta_{p 1} I_{\text {POST }, t}+\varepsilon_{p t}
$$

$\beta_{p 0}$ then represents an estimate of the pre-event volatility and $\beta_{p 1}$ represents the change in volatility from the pre-event. Newey-West standard errors with five lags are reported for the volatility change $\beta_{\mathrm{p} 1}$. More specifically, we estimate:

$$
\begin{aligned}
& \sqrt{\pi / 2}\left|R_{p t}^{N Y}\right|=\beta_{p 0}^{N Y}+\beta_{p 1}^{N Y} I_{P O S T, t}+\varepsilon_{p t}^{N Y}, \\
& \sqrt{\pi / 2}\left|R_{p t}^{N A S D}\right|=\beta_{p 0}^{N A S D}+\beta_{p 1}^{N A S D} I_{P O S T, t}+\varepsilon_{p t}^{N A S D} \\
& \operatorname{cov}\left(\varepsilon_{p t}^{N Y}, \varepsilon_{p t}^{N A S D}\right)=v, \\
& \operatorname{cov}\left(\varepsilon_{p s}^{N Y}, \varepsilon_{p t}^{N A S D}\right)=0 \forall s \neq t,
\end{aligned}
$$

The methodology described above does not account for differing volatility levels across the two markets. To control for unequal variances we follow Schwert and Seguin (1990) and model conditional heteroskedasticity for a portfolio as being linear in the predicted standard deviation of some aggregate portfolio factor. ${ }^{25}$ We specify the NYSE/AMEX firms as a function of the NASDAQ portfolio conditional on volatility. Given that NASDAQ transactions were largely not affected by New York State transfer taxes, we use the NASDAQ portfolio as a proxy for the single volatility factor.

Specifically, we first obtain the fitted value of daily NASDAQ portfolio return standard deviation by regressing the standard deviation of returns on the size-relevant NASDAQ portfolio at time $t$ onto 12 lags of daily returns. That is,

$$
\sigma_{p t}^{N A S D}=\beta_{0}+\sum_{i=1}^{12} \beta_{i} \sigma_{p t-i}^{N A S D}+\mu_{p t}
$$

where $\sigma_{p t}^{N A S D}$ is the absolute value of returns to the NASDAQ portfolio multiplied by $\sqrt{\pi / 2}$. We then use the fitted values in the following regression

$$
\sigma_{p t}^{N Y}=\gamma_{0}+\gamma_{1} \hat{\sigma}_{p t}^{N A S D}+\gamma_{2} \hat{\sigma}_{p t}^{N A S D} I_{p o s t, t}+\varepsilon_{p t}
$$

\footnotetext{
${ }^{25}$ Schwert and Seguin (1990) find that a single-factor model of standard deviations describes the cross sectional and time series characteristics of portfolio volatility as well as a GARCH model, and better than a linear variance-based specification.
} 
where $\sigma_{p t}^{N Y}$ is the standard deviation of a NYSE portfolio $p$ at time $t$ estimated as the absolute value of the return to the portfolio multiplied by $\sqrt{\pi / 2} ; I_{P O S T, t}$ is a dummy variable, taking on the value 0 for the pre-event period and 1 for the post event time frame; $\hat{\sigma}_{p t}^{N A S D}$ is the estimated standard deviation of returns on the size-relevant NASDAQ portfolio at time $t$, conditional on 12 lags of daily returns. The parameter estimate $\gamma_{1}$ then measures the level of NYSE/AMEX volatility relative to NASDAQ volatility.

To capture the effect of the STT change on volatility, we specify an interaction variable between the dummy and the NASDAQ portfolio standard deviation variable, $\hat{\sigma}_{p t}^{N A S D} I_{p o s t, t}$. This allows for the measurement of changes in volatility of our NYSE/AMEX sample firms as a result of a tax change, while using NASDAQ firms to control for conditional heteroskedasticity. Therefore, the parameter estimate $\gamma_{2}$ measures changes in the proportional level of NYSE/AMEX volatility. However, due to lack of data availability, we can only apply this methodology to events from 1971 on.

The next market quality measure we examine is spread width. This measure has not been previously examined in the extant literature. However, bid and ask data is not available for US stocks prior to the 1990s. Recently Holden (2009) has developed a low frequency proxy for effective spread width that Goyenko, Holden, and Trzcinka (2009) show provides good estimates of actual effective spread. We employ the Holden low frequency measure which is described in Appendix B.

Two other market quality variables of interest are volume and market share for exchanges in and out of New York around each tax change. Traders can switch their trading to an exchange outside of New York to avoid the New York STT if that opportunity exists. However, for the majority of our sample period, shares were traded in physical form so it was necessary for brokers and transfer agents to be close to each other to transfer actually securities. As a result, it was more difficult for investors to avoid the tax. In addition, while 
many NYSE stocks were traded on regional exchanges outside of New York, American Stock Exchange stocks were not. Therefore, we limit this part of the study to NYSE stocks. If traders do indeed switch to non-NYSE venues to avoid the tax then we should see a reduction in the NYSE's market share and volume following tax increases and an increase following tax reductions. To obtain the needed data, we hand collect monthly volume figures from the Bank and Quotation Record for each regional exchange as well as the NYSE. Market share is estimated as the total stock volume for each exchange in month $t$ divided by the total sum of volume on all exchanges. That is,

$$
\text { marketshare }_{x, t}=\frac{\text { volume }_{x, t}}{\sum_{x=1}^{n} \text { volume }_{x, t}}
$$

where $x$ represents the exchange in month $t$ with $n$ total exchanges at time $t$. To calculate impacts we average market share for each exchange over either the pre or post period.

The final market quality measure we examine is price impact. If an STT reduces volume then we would expect trades to have larger price impact, ceteris paribus. Again, due to data limitations during the period of our study we rely on low-frequency proxies for price impact. We rely on the Amihud (2002) price impact measure which has been shown by Goyenko, Holden and Trzcinka (2009) to be a good proxy for price impact. Amihud (2002) studies the time series relationship between returns and illiquidity and estimates illiquidity as an average of the daily ratio of unsigned stock returns to its dollar volume. Specifically, illiquidity is measured as

$$
\text { Amihud }=\frac{\left|r_{i, t}\right|}{\$ \text { Volume }_{i, t}}
$$

where $r_{i, t}$ and $\$$ Volume $_{i, t}$ are the stock return and dollar volume for stock $i$ on day $t$, respectively. This ratio can be interpreted as the daily price impact of order flow because it measures absolute price change per dollar of daily trading volume.

In the next section we discuss the results of tests to measure changes in our market quality measures around STT changes. 


\section{Results}

The first market quality measure we examine is volatility. Recall that proponents of an STT argue that the imposition or increase in the tax will reduce speculation and hence volatility. Therefore they predict an inverse relationship between an STT and volatility. However, only one (Roll (1989)) of the nine empirical papers cited in Table 1 that examine volatility finds evidence of an inverse relationship as predicted by proponents of the tax. ${ }^{26}$ All but one of the remaining papers finds no statistically significant relationship, while Jones and Seguin (1997) find a statistically significant direct relationship between the tax and volatility. We use the methodology of Jones and Seguin to examine the relationship between volatility and nine changes in the level of the New York State STT between 1932 and 1981.

The results of our regressions are found in Table 3. Panel A reports the date and nature of each change in the first column. The next column lists the percentage point change in the STT for a $\$ 5$ stock. The remaining columns show the parameter estimates for each change for stocks listed on the New York and American stock exchanges. The parameter estimate of interest is $\beta_{p 1}$ which measures the change in volatility following the change in the STT. Examining the parameter estimates in column four reveals that in five instances volatility appeared to change in the direction of the tax change $(1932,1933,1966,1980$, and 1981) while the level of volatility appears to move in the opposite direction of the tax change for four of the events $(1945,1975,1978$, and 1979). Only four of the nine estimates are statistically significant at acceptable levels and there is no consistent pattern among these four estimates.

It may very well be that the observed changes in volatility are the result of market wide changes in volatility unrelated to changes in the STT rate. To test for this we employ NASDAQ stocks as a control group. Since NASDAQ was located in Washington DC it was not subject to the tax on listed stocks. In addition, brokers and residents of states outside of New York were

\footnotetext{
${ }^{26}$ Only nine of the ten papers examine volatility. Liu (2007) does not.
} 
likewise exempt from the New York STT for stocks incorporated outside of New York. NASDAQ data are only available starting in $1975 .{ }^{27}$ Comparing the NASDAQ parameter estimates in column six to their counterparts for NYSE and AMEX stocks reveals that in all five comparisons, NASDAQ stock volatility changed in a direction similar to NYSE/AMEX stocks. Further four of the five NASDAQ parameter estimates are statistically significant suggesting that there may indeed have been market wide changes in volatility unrelated to the change in the STT. We test whether the NYSE/AMEX and NASDAQ parameter estimates are statistically similar using a Wald test. The Wald $p$ values are listed in the last column of Panel A in Table 3. The $p$ values suggest that the parameter estimates for NYSE/AMEX and NASDAQ are statistically indistinguishable providing further evidence that the observed changes in volatility are related to market wide changes and not changes in the STT. Taken together, the results reported in Panel A agree with the majority of the empirical papers listed in Table 1. There appears to be no statistically significant relationship between the level of an STT and volatility.

In Panel A we examine the absolute changes in volatility. However, this may not be appropriate measure of volatility if volatility varies across the NYSE/AMEX and NASDAQ portfolios. Therefore, in Panel B we present results for proportional changes in volatility. The first two columns in Panel B list the date and event tested and the percent change in the STT for a $\$ 5$ stock. The next three columns list the parameter estimates, followed by the $R^{2}$ in the last column. The parameter of interest is $\gamma_{2}$ which measures the proportional change in NYSE/AMEX volatility relative to NASDAQ following a change in the STT. For four $(1975,1979$, 1980, 1981) of the five events examined in Panel B, NYSE/AMEX volatility moves in the same direction as the STT change, however, only one parameter estimate is statistically significant.

\footnotetext{
${ }^{27}$ Prior to 1975, trading occurred when brokers contacted other brokers who were listed as trading a stock on the Pink Sheets. Quotes on the Pink Sheets were often stale and therefore closing prices were impossible to estimate. Beginning in 1975, NASDAQ automated the Pink Sheets for a large number of stocks and allowed for contemporaneous quote updating. Closing prices were based on the midpoint of the closing spread until 1980. At that time, NASDAQ market makers began reporting their trades contemporaneously and closing prices could therefore be determined.
} 
In particular, for the 1979 event, NYSE/AMEX volatility is on average $93 \%$ of NASDAQ volatility before the $30 \%$ rebate, but falls to $85 \%(0.927-0.076)$ of NASDAQ volatility after the STT decline. Thus, the results reported in Panel B agree with our previous findings, in that there appears to be no consistent statistically significant relationship between the level of an STT and volatility.

The next market quality measure we examine is spread width. This measure has not been previously examined in the extant literature. Since bid and ask data is not available for US stocks prior to the 1990s, we employ the Holden low frequency measure described in Appendix B. It has been shown to be a good proxy for effective spread. We first examine univariate changes in spread width surrounding our STT events. The pre-event, post-event, and change in spread are listed in Panel A of Table 4. Only NYSE and AMEX stocks are included in this table. Examining the average change in spread and comparing it to the change in STT reveals that in all cases spread width changed in the direction of the STT. In all but one case, the change is statistically significant at acceptable levels. Due to data limitations, we are unable to compute the Holden proxy for NASDAQ firms. ${ }^{28}$

The changes in spread reported in Panel A may be the result of changes in other variables known to be associated with spread width. Accordingly we perform control regressions of the form

$$
\text { Holden }_{i, t}=\beta_{0}+\beta_{1} \text { Vol }_{i, t}+\beta_{2} \sigma_{i, t}+\beta_{3} \text { Dummy }_{i, t}+\varepsilon_{i, t}
$$

where $\mathrm{Vol}$ is traded volume for stock $i$ on day $t, \sigma$ is measured by $\sqrt{\pi / 2}\left|R_{p t}\right|$, and Dummy takes the value 0 pre-event and 1 post-event. The parameter estimates of the control regression are found in Panel B of Table 4. Consistent with previous literature the parameter estimate for volume is mostly negative and that for volatility positive. The parameter of interest is $\beta_{3}$. Examining the estimates, only in one of the nine cases is the observed sign of the Dummy

${ }^{28}$ CRSP does not report NASDAQ volumes until the 1980 s. 
estimate of the opposite sign of the STT change. However, in the parameter estimate is not significant. Of the eight remaining cases where the parameter estimate and STT are of the same sign, six are statistically significant at acceptable levels. Based on the univariate and multivariate evidence in Table 4, we conclude that an STT has a direct relationship with spread width. That is, imposing or increasing an STT will be associated with wider spreads. For both the univariate and multivariate tests, consistent with our hypothesis, the 1933 event exhibits a larger change in spread than the 1932 event, indicating that per share taxes result in larger market quality changes than par value tax changes since the latter can be managed by corporations through par value changes.

Given the inverse relationship between spread width and volume documented in previous literature, and given that we find spreads to have a significant direct relationship with changes in STT levels, we would also expect volume to have an inverse relationship. Of the five papers listed in Table 1 that examine volume, all five find an inverse relationship between an STT and volume, but only one is statistically significant. Accordingly, we next examine volume. We must remember though that the STT changes we examine only impact New York State exchanges, corporations, and residents. Therefore we expect the impact of changes in the level of the New York STT to mostly impact New York exchanges. We must also remember that in some circumstances non-New York investors could avoid the tax by trading on exchanges outside of NY. Changes in STTs may induce those that can to switch trading to another exchange. Umlauf (1993) documents that the increase in Swedish transaction taxes in 1986 is associated with a dramatic shift in trading from Stockholm to London.

We therefore examine both market share and volume for the NYSE and regional exchanges in Table 5. Listed is the average market share and monthly share volume for each exchange before and after each New York STT change. During the time period of our study (1932-1981) an increasing portion of regional stock exchange volume was in NYSE listed 
stocks. ${ }^{29}$ Therefore, we expect that regional stock exchange market share would increase (decrease) when New York State increases (decreases) the level of the STT. However, because the New York State tax was applied as long as part of the transaction took place within the state (i.e. if the location of the exchange, contra broker or transfer agent is in New York or if the stock seller is domiciled in New York) and most brokers and transfer agents were located in New York, it may have been difficult for investors to shift their trading and avoid the STT. We find that for five of the nine STT changes $(1933,1945,1966,1975$, and 1978) the sign of NYSE market share change was opposite that of the STT sign change, and in four cases it was of the same sign. Therefore, our results are mixed. ${ }^{30}$

Some investors may not switch to (from) a regional exchange if there is an increase (decrease) in the New York STT. Some may just not trade certain stocks. Therefore, we must also look at volume since it captures volume switched to other exchanges as well as decisions to not trade at all. Examining NYSE volume in the last three columns of Table 5 reveals that, in eight of the nine STT changes, volume moved in the opposite direction of the tax change. Six of those eight cases are statistically significant at acceptable levels. Therefore we conclude that, consistent with previous empirical papers, STTs and volume are inversely related.

Since trading volume acts as a shock absorber for price impacts, we would also expect that changes in STT levels would affect measures of price impact. We examine that possibility by considering the Amihud measure. An increase in the Amihud measure indicates a decrease in liquidity in that a given volume will have a larger price impact. A direct relationship between the Amihud measure and changes in the STT would suggest that STTs harm market quality, while an inverse relationship would suggest that it improves it. Table 6 provides univariate changes in the Amihud measure surrounding STT level changes. Examining the change in the

\footnotetext{
${ }^{29}$ See Weaver (2008) for a discussion of the changing role of regional stock exchanges in the 20th Century.

${ }^{30}$ It is possible that the change in market share is related to other changing factors such as the increased use of technology and demographics. Due to data limitations we are unable to control for these changes.
} 
Amihud measure after the STT changed reveals that for seven of the nine STT changes the Amihud measure changed in the direction of the tax change and that all seven cases are statistically significant at acceptable levels. This suggests that STTs adversely impact market quality.

\section{Conclusion}

Security transaction taxes have been the subject of debate for decades among academics that develop models of the relationship between STTs and market quality, empiricists who examine the relationships for existing taxes, and governments seeking to raise revenue without harming economic growth. In spite of the length of the debate, no consensus has yet been reached. We add to the debate by examining the impact on market quality of nine changes to the New York State STT between the first significant change to it in 1932 and its repeal in 1981.

We find that increasing an STT is accompanied by an increase in transaction costs for investors, a reduction in volume, and higher price impact for trades. We find no consistent relationship that suggests that investors will switch trading to non taxing venues to avoid the tax, but do find that corporations will manage par values in the direction of minimizing taxes if they are based on par value. Finally, we find no support for the notion that STTs reduce volatility.

Our findings largely come down on the side of opponents of the tax who suggest that an STT will harm market quality. Since spreads have been shown to be directly related to a firm's cost of capital, imposing an STT may hinder economic growth by reducing the present value of projected profits. 


\section{References}

Amihud, Y., 2002, Illiquidity and stock returns: cross-section and time-series effects, Journal of Financial Markets 5 pp. 31-56.

Amihud, Y and Mendelson, H., 1992, Transaction Taxes and Stock Values, in K. Lehn and R. W. Kamphuis, Jr. (eds.), Modernizing U.S. Securities Regulations, pp. 477-500, Irwin Professional Publishing.

Amihud, Y and Mendelson, H., 2003, Effects of a New York State Stock Transaction Tax, Unpublished manuscript (November).

Baltagi, B, Li, D. and Li, Q., 2006, Transaction Tax and Stock Market Behavior: Evidence from an Emerging Market, Empirical Economics 31 pp. 393-408.

Bloomfield, R., O'Hara, M. and Saar, G., 2009, How Noise Trading Affects Market: An Experimental Analysis, Review of Financial Studies 22(6) pp. 2275-2302.

"Brokers Assail Stock Tax Plan," New York Times, Mar 26, 1933, p. N8.

Campbell, J. Y. and Froot, K., 1994, International Experiences with Securities Transaction Taxes. In J. Frankel (Ed), The internationalization of equity markets (pp. 277-308). Chicago: University of Chicago Press.

Christie, W., Schultz, P., 1994, Why do NASDAQ market makers avoid odd-eighth quotes?, Journal of Finance 49 pp. 1813-1840.

“Germany, France Press EU on Transaction Tax” Wall Street Journal, July 9, 2011.

Goyenko, R.Y., C. Holden, and C. W., Trzcinka, 2009, Do liquidity measures measure liquidity? Journal of Financial Economics, 92, 153-181.

Hau, H., 2006, The Role of Transaction Costs for Financial Volatility: Evidence from the Paris Bourse, Journal of the European Economic Association 4(4) pp. 862-90.

Holden, C., 2009, New low-frequency liquidity measures, Journal of Financial Markets 12 pp $778-813$.

Hu, S., 1998, The Effects of the Stock Transaction Tax on the Stock Market-Experience from Asian Markets, Pacific Basin Finance Journal 6 pp. 347-64.

Huang, R., Stoll, H., 1997, The components of the bid-ask spread: a general approach, Review of Financial Studies 10 pp. 995-1034.

Jarrell, G. A., 1984, "Change at the Exchange: The Causes and Effects of Deregulation." Journal of Law and Economics, 27(2), pp. 273-312.

Johnson, N. L. and Kotz, S., 1970, Continuous Univariate Distributions. Boston: Houghton Mifflin. 
Jones, C.M. and Seguin, P., 1997, Transaction costs and price volatility: Evidence from commission deregulation, American Economic Review 87 pp. 728-37.

Liu, S., 2007, Securities Transaction Tax and Market Efficiency: Evidence from the Japanese Experience, Journal of Financial Services Research, 32: pp. 161-76.

Keynes, J.M., 1936, The General Theory of Employment, Interest and Money. MacMillan, London.

Kupiec, P., 1996, Noise Traders, Excess Volatility, and a Securities Transaction Tax, Journal of Financial Services Research 10 pp. 115-29.

Phylaktis, K. and Aristidou, A., 2007, Security transaction taxes and financial volatility: Athens stock exchange, Applied Financial Economics, Taylor and Francis Journals 17(18), pp1455-1467.

Roll, R., 1989, Price volatility, international market links, and their implications for regulatory policies, Journal of Financial Services Research 3 pp. 211-46.

Sahu, D., 2008, Does Securities Transaction Tax Distort Market Microstructure? Evidence from Indian Stock Market, Working Paper, Banaras Hindu University.

Saporta, V. and Kan, K., 1997, The effects of stamp duty on the level and volatility of UK equity prices, Bank of England Working Paper No. 71, July.

Schwert, G. W., and Seguin, P,1990, Heteroscedasticity in Stock Returns, Journal of Finance 45 pp 1129-1155.

Schwert, G.W., and Seguin, P, 1993, Securities Transaction Taxes: An Overview of Costs, Benefits and Unresolved Questions, Financial Analysts Journal pp. 27-35.

Stiglitz, J.E., 1989, Using tax policy to curb speculative short-term trading, Journal of Financial Services Research 3 pp. 101-15.

"Stock-Deal Taxes and Their Effects", New York Times, 10 December 1939.

"Stock Transfer Tax Amendment," Wall Street Journal, Jun 4, 1913, p. 7.

“Stock-Transfer Tax Cut Is Signed," New York Times, 23 June 1968, p.44.

Summers, L. H. and Summers, V. P., 1989, When financial markets work too well: a cautious case for a securities transaction tax, Journal of Financial Service Research 3 pp. 26186.

Tobin, J., 1978, A proposal for international monetary reform, Eastern Economic Journal 4 pp. $153-59$.

“The Stock Transfer Tax”, New York Times, 14 March 1905.

“Transfer Tax Bill Signed”, New York Times, 20 April 1945. 
Umlauf, S.R., 1993, Transaction taxes and the behaviour of the Swedish stock market, Journal of Financial Economics 33 pp. 227-40.

U.S Supreme Court. Boston Stock Exchange v. State Tax Comm'n, 429 U.S. 318 (1977)

“Wall St. Sees End of Stock Sales Tax”, New York Times, 4 July 1916.

Weaver, D., 2008, "Networks, Nodes, and Priority Rules", The Encyclopedia of Finance, edited by Cheng-few Lee and Alice C. Lee, Springer Publishing. 2008.

Zelinsky, E., 2002, Restoring Politics to the Commerce Clause: The Case for Abandoning the Dormant Commerce Clause Prohibition on Discriminatory Taxation, Ohio Northern University Law Review 


\section{Appendix A}

Changes in the New York State Security Transaction Tax This appendix summarizes changes in the New York State Security Transaction Tax from its imposition in 1905 to its elimination in 1981. Beginning in 1932 the tax was charged on a per share basis. At various points during the reign of the tax, state residents were taxed differently than non-residents. For these reasons we list the effective tax for New York State residents (Panel A) and non-residents (Panel B) separately. We also list the effective tax per share for stocks of different prices as listed in tax legislation. In both Panels, $\mathrm{P}$ is the security price and the last column indicates the general direction of the tax rate.

Panel A: Effective tax rate on per share basis for residents placing orders in New York

\begin{tabular}{|c|c|c|c|c|c|}
\hline Date & $P<\$ 5$ & $\$ 5<\mathrm{P}<\$ 10$ & $\$ 10<P<\$ 20$ & $\$ 20<P$ & $\begin{array}{c}\text { Change to State } \\
\text { STT }\end{array}$ \\
\hline June 1, 1905 & \multicolumn{4}{|c|}{$\begin{array}{l}\$ 0.02 \text { on } \$ 100 \text { par value of stock transferred in New York } \\
\text { State on round lots. }\end{array}$} & Began \\
\hline $\begin{array}{l}\text { March 1, } \\
1932\end{array}$ & \multicolumn{4}{|c|}{$\begin{array}{l}\$ 0.04 \text { on } \$ 100 \text { par value of stock transferred in New York } \\
\text { State on round lots. }\end{array}$} & Doubled \\
\hline June 2, 1933 & & $\$ 0.030$ & & $\$ 0.040$ & $\begin{array}{l}\text { Changed to per } \\
\text { share basis }\end{array}$ \\
\hline July 1, 1945 & $\$ 0.010$ & $\$ 0.020$ & $\$ 0.030$ & $\$ 0.040$ & $\begin{array}{l}\text { Reduced for stocks } \\
\text { less than } \$ 10\end{array}$ \\
\hline July 1, 1966 & $\$ 0.013$ & $\$ 0.025$ & $\$ 0.038$ & $\$ 0.050$ & $25 \%$ increase \\
\hline Oct 1, 1968 & $\$ 0.013$ & $\$ 0.025$ & $\$ 0.038$ & $\$ 0.050$ & Capped at $\$ 350$ \\
\hline Aug. 1, 1975 & $\$ 0.016$ & $\$ 0.031$ & $\$ 0.047$ & $\$ 0.063$ & $25 \%$ surcharge \\
\hline Aug. 1, 1978 & $\$ 0.013$ & $\$ 0.025$ & $\$ 0.038$ & $\$ 0.050$ & $\begin{array}{l}25 \% \text { surcharge } \\
\text { expires }\end{array}$ \\
\hline Oct 1,1979 & $\$ 0.009$ & $\$ 0.002$ & $\$ 0.026$ & $\$ 0.035$ & After $30 \%$ rebate \\
\hline Oct. 1, 1980 & $\$ 0.005$ & $\$ 0.010$ & $\$ 0.015$ & $\$ 0.020$ & After $60 \%$ rebate \\
\hline Oct 1, 1981 & $\$ 0.000$ & $\$ 0.000$ & $\$ 0.000$ & $\$ 0.000$ & After $100 \%$ rebate \\
\hline
\end{tabular}




\section{Appendix A}

(continued)

Panel B: Effective tax rate on per share basis for non-residents placing orders in NY

\begin{tabular}{|c|c|c|c|c|c|}
\hline Year & $P<\$ 5$ & $\$ 5<P<\$ 10$ & $\$ 10<P<\$ 20$ & $\$ 20<P$ & $\begin{array}{l}\text { Change to State } \\
\text { STT }\end{array}$ \\
\hline June 1, 1905 & \multicolumn{4}{|c|}{$\begin{array}{c}\$ 0.020 \text { on } \$ 100 \text { par value of stock transferred in New } \\
\text { York State on round lots. }\end{array}$} & Imposed \\
\hline March 1, 1932 & \multicolumn{4}{|c|}{$\begin{array}{c}\$ 0.040 \text { on } \$ 100 \text { par value of stock transferred in New } \\
\text { York State on round lots. }\end{array}$} & Doubled \\
\hline June 2, 1933 & & $\$ 0.030$ & & $\$ 0.040$ & $\begin{array}{l}\text { Changed to per } \\
\text { share basis }\end{array}$ \\
\hline July 1, 1945 & $\$ 0.010$ & $\$ 0.020$ & $\$ 0.030$ & $\$ 0.040$ & $\begin{array}{l}\text { Reduced for stocks } \\
\text { less than } \$ 10\end{array}$ \\
\hline July 1, 1966 & $\$ 0.013$ & $\$ 0.025$ & $\$ 0.038$ & $\$ 0.050$ & $25 \%$ increase \\
\hline Oct 1, 1968 & $\$ 0.013$ & $\$ 0.025$ & $\$ 0.038$ & $\$ 0.050$ & Capped $\$ 350$ \\
\hline July 1, 1969 & $\$ 0.012$ & $\$ 0.024$ & $\$ 0.036$ & $\$ 0.048$ & Paid 95\% \\
\hline July 1,1970 & $\$ 0.011$ & $\$ 0.023$ & $\$ 0.034$ & $\$ 0.045$ & Paid $90 \%$ \\
\hline July 1, 1971 & $\$ 0.010$ & $\$ 0.020$ & $\$ 0.030$ & $\$ 0.040$ & Paid $80 \%$ \\
\hline July 1, 1972 & $\$ 0.008$ & $\$ 0.016$ & $\$ 0.024$ & $\$ 0.033$ & Paid $65 \%$ \\
\hline July 1,1973 & $\$ 0.006$ & $\$ 0.013$ & $\$ 0.019$ & $\$ 0.025$ & Paid 50\% \\
\hline Aug 1, 1975 & $\$ 0.008$ & $\$ 0.016$ & $\$ 0.023$ & $\$ 0.031$ & $25 \%$ surcharge \\
\hline April 17, 1978 & $(\$ 0.000)$ & $(\$ 0.000)$ & $(\$ 0.000)$ & $(\$ 0.000)$ & $\begin{array}{l}\text { (rates for ITS } \\
\text { orders) }\end{array}$ \\
\hline Aug 1, 1978 & $\begin{array}{c}\$ 0.008 \\
(\$ 0.000)\end{array}$ & $\begin{array}{l}\$ 0.012 \\
(\$ 0.000)\end{array}$ & $\begin{array}{c}\$ 0.023 \\
(\$ 0.000)\end{array}$ & $\begin{array}{l}\$ 0.031 \\
(\$ 0.000)\end{array}$ & $\begin{array}{l}\text { non-residents pay } \\
62.5 \% \text { coincide } w \text {. } \\
\text { surcharge } \\
\text { expiration }\end{array}$ \\
\hline Oct. 1, 1979 & $\begin{array}{l}\$ 0.006 \\
(\$ 0.0)\end{array}$ & $\begin{array}{l}\$ 0.001 \\
(\$ 0.0)\end{array}$ & $\begin{array}{l}\$ 0.023 \\
(\$ 0.0)\end{array}$ & $\begin{array}{l}\$ 0.022 \\
(\$ 0.0)\end{array}$ & $\begin{array}{l}\text { non-residents pay } \\
62.5 \%\end{array}$ \\
\hline Oct. 1, 1980 & $\begin{array}{c}\$ 0.005 \\
(\$ 0.000)\end{array}$ & $\begin{array}{l}\$ 0.010 \\
(\$ 0.000)\end{array}$ & $\begin{array}{l}\$ 0.015 \\
(\$ 0.000)\end{array}$ & $\begin{array}{l}\$ 0.020 \\
(\$ 0.000)\end{array}$ & After $60 \%$ rebate \\
\hline Oct. 1, 1981 & $\$ 0.000$ & $\$ 0.000$ & $\$ 0.000$ & $\$ 0.000$ & After $100 \%$ rebate \\
\hline
\end{tabular}




\section{Appendix B}

\section{The Holden Model for Estimating Spreads from Low Frequency Data}

The Holden (2009) model is an extension of Huang and Stoll (1997) and allows for the spread to change daily. Specifically, $V_{t}$ is the fundamental stock value at the end of day $t$ and develops as

$$
V_{t}=V_{t-1}+\frac{1}{2} \alpha S_{t-1} Q_{t-1}+\varepsilon_{t}
$$

where $S_{t-1}$ is the effective spread, $\alpha$ is the portion of the half-spread resulting from adverse selection $Q_{t-1}$ is the trade indicator that specifies a buy/sell/no trade transaction and $\varepsilon_{t}$ is the public information shock.

The probability that a closing trade occurs at the bid is $\frac{\mu}{2}$, the probability of a closing trade occurring at the ask is $\frac{\mu}{2}$ and $1-\mu$ is the probability of a no trade day. ${ }^{31}$ Then the trade indicator variable $Q_{t}$ can be classified into three categories as

$$
Q_{t} \equiv\left\{\begin{array}{l}
+1 \text { Closing trade is a buy }\left(\operatorname{prob}=\frac{\mu}{2}\right) \\
0 \text { Closing midpoint }(\mathrm{prob}=1-\mu) \\
-1 \text { Closing trade is a buy }\left(\operatorname{prob}=\frac{\mu}{2}\right)
\end{array}\right.
$$

Let $M_{t}$ be the unobserved midpoint of the bid-ask spread, which is dependent on the assets fundamental value and inventory effects

$$
M_{t}=V_{t}+\omega_{t},
$$

where $\omega_{t}$ is the inventory effect up to day $t$.

Substituting equation (B.1) into the first difference of equation (B.3) generates the daily change in the midpoint of the bid-ask spread,

\footnotetext{
${ }^{31}$ CRSP reports a closing midpoint on no trade days
} 


$$
\Delta M_{t}=\frac{1}{2} \alpha S_{t-1} Q_{t-1}+\varepsilon_{t}+\Delta \omega_{t}
$$

Let $P_{t}$ be the observed closing price which is defined by

$$
P_{t}=M_{t}+\frac{1}{2} S_{t} Q_{t}+\eta_{t}\left(S_{t}\right)
$$

where $\eta_{t}\left(S_{t}\right)$ is the error term with $E\left[\eta_{t}\left(S_{t}\right)\right]=0$. The error term accounts for rounding the transaction price to the same price cluster as the spread $S_{t}$. That is, when $S_{t}=1 / 4$, the price is rounded to the closest $\$ 1 / 4(\$ 1 / 4, \$ 1 / 2$, etc).

Substituting equation (B.4) into (B.5) gives the price change process as

$$
\Delta P_{t}=\frac{1}{2} S_{t} Q_{t}-(1-\alpha) \frac{1}{2} S_{t-1} Q_{t-1}+e_{t}
$$

where $e_{t}$ is normally distributed with $\bar{e}$ mean and $\sigma_{e}$ standard deviation, and $e_{t} \equiv \varepsilon_{t}+\Delta \eta_{t}+\Delta \omega_{t}$

Next, the half spread $H_{t}$ is defined as

$$
H_{t} \equiv \frac{1}{2} S_{t} Q_{t}
$$

Combining (B.1) and (B.2) and solving for the error term in terms of the half spread and the price changes yields

$$
e_{t}=\Delta P_{t}-\left(H_{t}-(1-\alpha) H_{t-1}\right)
$$

Equation (B.3) is later used when maximizing the likelihood function.

Holden includes price clustering into his model due to the relationship between observed price clusters and the bid-ask spread. Christie and Schultz (1994) find that NASDAQ dealers avoid odd eighths to maintain larger spreads. For example, if transaction prices are on even eighths $(\$ 1 / 4$, $\$ 1 / 2, \$ 3 / 4, \$ 1)$ then the bid-ask spread is at least $\$ 1 / 4$. While if prices are on odd eighths $(\$ 1 / 8, \$ 3 / 8$, $\$ 5 / 8$, and $\$ 7 / 8$ ) then the bid-ask spread is likely be $\$ 1 / 8$. Therefore, by avoiding odd eighths, dealers can lock in larger spreads. 
Following Christie and Schultz (1994), the Holden model assumes that the daily effective spread, $S_{t}$ is the increment of the price cluster on day $t . S_{t}$ is randomly chosen from a set of possible effective spreads $s_{j}, j=1,2, \ldots, J$ ordered from smallest to largest, and have corresponding probabilities $\gamma_{j}, j=1,2, \ldots, J$. That is, for a price on $\$ 1 / 8, S_{t}$ has a probability $\gamma_{1}$ of effective spread $s_{1}=\$ \frac{1}{8}$, probability $\gamma_{2}$ of effective spread $s_{2}=\$ \frac{1}{4}$, probability $\gamma_{3}$ of effective spread $s_{3}=\$ \frac{1}{2}$, and probability $\gamma_{4}$ of effective spread $s_{4}=\$ 1$ Given an effective spread, the model assumes that the closing price is evenly distributed on the corresponding price increments [i.e. when $s_{1}=\$ \frac{1}{8}$ then the closing price is equally likely to be on any of the eight possible price increments $(\$ 1 / 8, \$ 2 / 8$, $\$ 3 / 8, \ldots, \$ 8 / 8)]$.

Let $C_{t}=1,2, \ldots, J$ represent the observable cluster of special prices that correspond to the effective spreads $s_{1}, s_{2}, \ldots, s_{J}$ on day $t$ and $C_{t}=J+1, J+2, \ldots, 2 J$ represent the clusters of special midpoints for non-trading days that correspond to the effective spreads $s_{1}, s_{2}, \ldots, s_{J}$. Figure B.1 (Figure 1 from Holden 2009) illustrates how the probabilities of price clusters and the conditional probabilities of half spreads are determined. Price clusters are assigned based on the prices and for each cluster, all possible half spreads are determined. Once price clusters are assigned to each price, the probability of each cluster and conditional probability of a half spread given a price cluster is then determined.

Figure B.1 below presents the set up of the Holden (2009) proxy using a $\$ 1 / 8$ price grid, which has four possible effective spreads: $s_{1}=\$ \frac{1}{8}$ with probability $\gamma_{1}, s_{2}=\$ \frac{1}{4}$ probability $\gamma_{2}, s_{3}=\$ \frac{1}{2}$ with probability $\gamma_{3}$, and $s_{4}=\$ 1$ with probability $\gamma_{4} \cdot{ }^{32}$ From these points on the price grid, the next part of the indicator $Q_{t}$ which is the buy/sell/midpoint variable is reached. From this point the observable

\footnotetext{
${ }^{32}$ All periods studied in this paper are during the period when US exchanges used a $\$ 1 / 8$ pricing grid.
} 
price/midpoint clusters can be reached. For example, using Holden (2009) Figure 1 and following the buy side of a spread $s_{1}=\$ \frac{1}{8}$, the probability of a buy $Q_{t}=1$ occurs with probability $\frac{\mu}{2}$. From here there are four possible price clusters

$$
\begin{aligned}
& C_{t}=1 \text { represents odd } \$ 1 / 8 \text { prices, } C_{t}=2 \text { represents odd } \$ 1 / 4 \text { prices, } \\
& C_{t}=3 \text { represents odd } \$ 1 / 2 \text { prices, } C_{t}=4 \text { represents } \$ 1 \text { prices. }
\end{aligned}
$$

It then follows, from the assumption that closing prices are uniformly distributed, that the probabilities of price clusters are $1 / 2,1 / 4,1 / 8,1 / 8$, respectively. Each price cluster also has a unique set of half spreads which are also determined from the price grid and used in the likelihood function.

To estimate the Holden model a likelihood function is first estimated by maximum likelihood (ML) and the parameter estimates are then used to compute the effective spread measures.

On three consecutive trading days, there are three observable prices $\left(P_{t}, P_{t+1}, P_{t+2}\right)$ which correspond to a price cluster triplet and a half spread triplet $\left(C_{t}, C_{t+1}, C_{t+2}\right),\left(H_{t}, H_{t+1}, H_{t+2}\right)$, respectively. The half spreads are unique to each price cluster and are determined from each cluster. For example, an odd eighth price such as $\$ 201 / 8$ is assigned to price cluster $C_{t}=1$, and has a single possible spread, $S_{t}=\$ \frac{1}{8}$. From this spread there are only two possible half spreads $H_{t} \in\{\$ 1 / 16, \$-1 / 16\}$. $P_{t+1}$ and $P_{t+2}$ correspond to half spreads $H_{t+1}$ and $H_{t+2}$ in the same way.

Next, the likelihood function is constructed and can be estimated using $\mathrm{ML}$ for each price triplet as

$$
\begin{aligned}
\operatorname{Pr} & \left(P_{t}, P_{t+1}, P_{t+2} \mid \mu, \hat{\gamma}_{1}, \hat{\gamma}_{2}, \ldots, \hat{\gamma}_{J-1}, \bar{e}, \sigma_{e}, \alpha\right) \\
\quad= & \sum_{\left(H_{t}, H_{t+1}, H_{t+2}\right) \in H}\left\{\begin{array}{l}
\operatorname{Pr}\left(C_{t}\right) \cdot \operatorname{Pr}\left(C_{t+1}\right) \cdot \operatorname{Pr}\left(C_{t+2}\right) \cdot \operatorname{Pr}\left(H_{t} \mid C_{t}\right) \cdot \operatorname{Pr}\left(H_{t+1} \mid C_{t+1}\right) \cdot \operatorname{Pr}\left(H_{t+2} \mid C_{t+2}\right) \\
n\left(P_{t+1}-H_{t+1}-\left(P_{t}-(1-\alpha) H_{t}\right)\right) \cdot n\left(P_{t+2}-H_{t+2}-\left(P_{t+1}-(1-\alpha) H_{t+1}\right)\right)
\end{array}\right\}
\end{aligned}
$$

where $\mu$ is the probability of a trading day, $\hat{\gamma}_{1}, \hat{\gamma}_{2}, \ldots, \hat{\gamma}_{J-1}$ are the spread probabilities except for the largest spread, $\bar{e}$ is the mean of the error term, $\sigma_{e}$ is the standard deviation of the error term, $\alpha$ is the percentage of the spread attributed to the adverse selection component, $n()$ is the normal 
density with mean $\bar{e}$ and standard deviation $\sigma_{e}$ and $\operatorname{Pr}\left(C_{t}\right)$ and $\operatorname{Pr}\left(H_{t} \mid C_{t}\right)$ is the probability of a price cluster and conditional probability of a half spread given a price cluster, which are calculated based on the price grid (see Figure B.1 below).

Taking the log of the above likelihood function gives the general likelihood function, which sums all the log likelihoods of all price triplets over the time period

$$
\sum_{t=1}^{T-2} \operatorname{Ln}\left(\operatorname{Pr}\left(P_{t}, P_{t+1}, P_{t+2} \mid \mu, \hat{\gamma}_{1}, \hat{\gamma}_{2}, \ldots, \hat{\gamma}_{J-1}, \bar{e}, \sigma_{e}, \alpha\right)\right) \text {, }
$$

where $T$ represents the number of days in the time period. The likelihood function is maximized subject to constraints:

$\mu, \hat{\gamma}_{1}, \hat{\gamma}_{2}, \ldots, \hat{\gamma}_{J}, \sigma_{e}, \alpha \geq 0$ and $\mu, \hat{\gamma}_{1}, \hat{\gamma}_{2}, \ldots, \hat{\gamma}_{J}, \alpha \leq 1$, where the contraints on $\hat{\gamma}_{J}$ are expressed as $1-\sum_{j=1}^{J-1} \hat{\gamma}_{J} \geq 0$ and $1-\sum_{j=1}^{J-1} \hat{\gamma}_{J} \leq 1$.

Once the likelihood function is estimated the effective spread can be calculated as

$$
\text { Holden }=\frac{\sum_{j=1}^{J} \hat{\gamma}_{j} s_{j}}{\bar{P}},
$$

where $\bar{P}$ is the mean of the closing prices, $\hat{\gamma}_{j}$ is the estimated spread probabilities which sum to one and $s_{j}$ is the possible spread. 
Figure B.1

Probabilities Of Price Clusters And The Conditional Probabilities Of Half Spreads Figure 1 from Holden (2009)

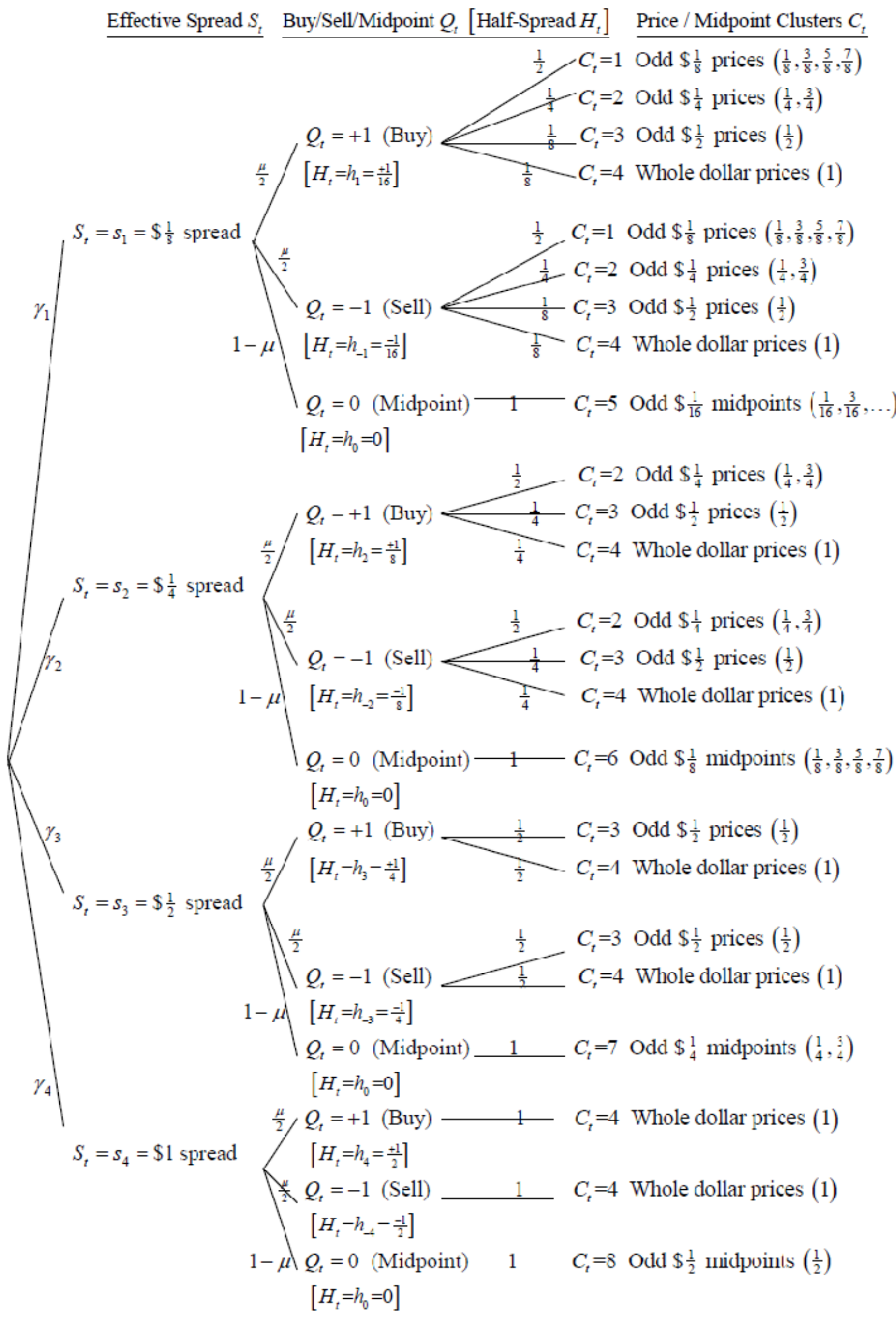


Table 1

\section{Summary of Results of Previous Empirical Papers}

This table summarizes the results of empirical papers that examine the relationship between Security Transaction Taxes (STT) and the quality of equity markets. All but one of the papers examines changes in the STT or quasi STT. For each paper we list the country examined, the STT change year, and the change. The last Colum lists the market quality measures considered and the reported relationship with the STT change. If the relationship is found to be statistically significant, it is indicated by an asterisk $\left({ }^{*}\right)$. Panel A lists those papers that examine STTs while Panel B lists those papers that examine quasi STTs.

\begin{tabular}{|c|c|c|c|c|c|}
\hline \multicolumn{6}{|c|}{ A. Changes in STT } \\
\hline Paper & Country & Year(s) & $\begin{array}{l}\text { Change } \\
\text { From }\end{array}$ & $\begin{array}{c}\text { Change } \\
\text { to }\end{array}$ & Measures Examined and Finding \\
\hline \multirow{2}{*}{$\begin{array}{l}\text { Umlauf } \\
(1993)\end{array}$} & \multirow{2}{*}{ Sweden } & 1984 & $0 \%$ & $1 \%$ & \multirow{2}{*}{$\begin{array}{l}\text { Volatility - Direct } \\
\text { Price Levels - Inverse } \\
\text { Market Share - Inverse }\end{array}$} \\
\hline & & 1986 & $1 \%$ & $2 \%$ & \\
\hline $\begin{array}{l}\text { Baltagi, } \\
\mathrm{Li} \text { and } \mathrm{Li} \\
(2006)\end{array}$ & China & 1997 & $0.3 \%$ & $0.5 \%$ & $\begin{array}{l}\text { Volume - Inverse } \\
\text { Volatility - Direct }\end{array}$ \\
\hline \multirow{14}{*}{$\begin{array}{l}\mathrm{Hu} \\
(1998)\end{array}$} & \multirow{3}{*}{$\begin{array}{l}\text { Hong } \\
\text { Kong }\end{array}$} & 1991 & $0.6 \%$ & $0.5 \%$ & \multirow{14}{*}{$\begin{array}{l}\text { Price Levels - Inverse* } \\
\text { Volatility - No relationship } \\
\text { Volume - Inverse for small stocks. No } \\
\text { relationship for large stocks. }\end{array}$} \\
\hline & & 1992 & $0.5 \%$ & $0.4 \%$ & \\
\hline & & 1993 & $0.4 \%$ & $0.3 \%$ & \\
\hline & \multirow{2}{*}{ Japan } & 1977 & $0.3 \%$ & $0.45 \%$ & \\
\hline & & 1980 & $0.45 \%$ & $0.55 \%$ & \\
\hline & \multirow{5}{*}{ Korea } & 1978 & $0.0 \%$ & $0.5 \%$ & \\
\hline & & 1979 & $0.5 \%$ & $0.25 \%$ & \\
\hline & & 1987 & $0.25 \%$ & $0.5 \%$ & \\
\hline & & 1990 & $0.5 \%$ & $0.2 \%$ & \\
\hline & & 1994 & $0.2 \%$ & $0.35 \%$ & \\
\hline & \multirow{4}{*}{ Taiwan } & 1978 & $0.15 \%$ & $0.3 \%$ & \\
\hline & & 1985 & $0.3 \%$ & $0.0 \%$ & \\
\hline & & 1986 & $0.0 \%$ & $0.3 \%$ & \\
\hline & & 1993 & $0.3 \%$ & $0.6 \%$ & \\
\hline $\begin{array}{c}\text { Liu } \\
(2007)\end{array}$ & Japan & 1989 & $0.55 \%$ & $0.3 \%$ & $\begin{array}{l}\text { Price Levels - Inverse } \\
\text { Volume - Inverse }\end{array}$ \\
\hline $\begin{array}{c}\text { Roll } \\
(1989)\end{array}$ & $\begin{array}{c}23 \\
\text { countries }\end{array}$ & \multicolumn{2}{|c|}{$\begin{array}{l}\text { January } 1987 \text { to } \\
\text { March } 1989\end{array}$} & \begin{tabular}{|c|} 
Cross- \\
country \\
regressions
\end{tabular} & Volatility - Inverse \\
\hline \multirow{4}{*}{$\begin{array}{c}\text { Saporta } \\
\text { and Kan } \\
\text { (1997) }\end{array}$} & \multirow{4}{*}{ UK } & 1963 & $2 \%$ & $1 \%$ & \multirow{4}{*}{$\begin{array}{l}\text { Price Levels - Inverse } \\
\text { Volatility - No relationship }\end{array}$} \\
\hline & & 1974 & $1 \%$ & $2 \%$ & \\
\hline & & 1984 & $2 \%$ & $1 \%$ & \\
\hline & & 1986 & $1 \%$ & $0.5 \%$ & \\
\hline
\end{tabular}


Table 1

Summary of Results of Previous Empirical Papers

(continued)

\begin{tabular}{|c|c|c|c|c|c|}
\hline \multicolumn{6}{|c|}{ A. Changes in STT (continued) } \\
\hline Paper & Country & Year(s) & $\begin{array}{c}\text { Change } \\
\text { From }\end{array}$ & $\begin{array}{c}\text { Change } \\
\text { to }\end{array}$ & Measures Examined and Finding \\
\hline $\begin{array}{l}\text { Sahu } \\
(2008)\end{array}$ & India & 2004 & 0.0 & $0.15 \%$ & $\begin{array}{l}\text { Volume - Inverse } \\
\text { Volatility - No relationship }\end{array}$ \\
\hline \multirow{3}{*}{$\begin{array}{l}\text { Phylaktis } \\
\text { and } \\
\text { Aristidou } \\
\text { (2007) }\end{array}$} & \multirow{3}{*}{$\begin{array}{l}\text { Athens } \\
\text { Stock } \\
\text { Exchange }\end{array}$} & 1998 & 0.0 & $0.3 \%$ & \multirow{3}{*}{$\begin{array}{l}\text { Price Levels - No relationship } \\
\text { Volatility - no impact in "normal" economic } \\
\text { conditions, but direct relationship during bull } \\
\text { markets }\end{array}$} \\
\hline & & 1999 & $0.3 \%$ & $0.6 \%$ & \\
\hline & & 2000 & $0.6 \%$ & $0.3 \%$ & \\
\hline \multicolumn{6}{|c|}{ B. Changes in Quasi-STT } \\
\hline Paper & Country & Year & \multicolumn{2}{|c|}{ Event } & Measures Examined and Finding \\
\hline $\begin{array}{l}\text { Jarrell } \\
(1984)\end{array}$ & USA & 1975 & \multicolumn{2}{|c|}{$\begin{array}{c}\text { Deregulation of } \\
\text { fixed commissions } \\
\text { Up to } 1 \%\end{array}$} & Volume - Inverse \\
\hline $\begin{array}{l}\text { Jones } \\
\text { and } \\
\text { Seguin } \\
(1997)\end{array}$ & USA & 1975 & \multicolumn{2}{|c|}{$\begin{array}{c}\text { Deregulation of } \\
\text { fixed commissions } \\
\text { Up to } 1 \%\end{array}$} & Volatility - Direct ${ }^{*}$ \\
\hline $\begin{array}{c}\mathrm{Hau} \\
(2006)\end{array}$ & France & 2004 & \multicolumn{2}{|c|}{$\begin{array}{c}\text { Increases in } \\
\text { transaction costs }\end{array}$} & Volatility - Direct \\
\hline
\end{tabular}




\section{Table 2 \\ Summary Statistics}

This table lists summary statistics for NYSE/AMEX stocks following nine changes in the New York State Stock Transfer Tax over the period 1932 to 1981 (when the tax was abolished). NASDAQ stocks, when available, are used as a control sample. Sample stocks are all those continuously traded one of the two New York stock exchanges - the NYSE and AMEX one year pre- and one year post- each tax change. There are four exceptions to this due to the proximity of confounding events. For the March 1932 increase, twelve months pre are used and eleven months post (June 1932 to May 1933) are used to combine the New York STT doubling with the Federal STT doubling and to control for the New York STT change from par values to per share. For the July 1966 New York state tax increase, six months pre and post are used to avoid the January 1966 elimination of the federal security transaction tax. Similarly, fixed commissions were abolished three months prior to the August 1975 STT increase. Therefore the 1975 event uses three months pre and post. Finally, between April and November regional exchanges join the Intermarket Trading system which gives them a rebate on the tax for orders placed through them to New York. Accordingly we define the post period as December 1978 through June 1979. For each event we list the percentage change in the security transaction tax for a stock with a market price and par value of $\$ 5$. Descriptive statistics given for both samples include the cross-sectional average price per share on the day prior to each event, the average market value (millions) on the day prior to each event and the standard deviation of daily equally weighted portfolio returns for the trading period prior to each event.

(Table on next page) 
Table 2

Summary Statistics

(continued)

\begin{tabular}{|c|l|c|c|c|c|c|c|c|c|}
\hline & & \multicolumn{3}{|c|}{ NYSE/AMEX } & \multicolumn{3}{|c|}{ NASDAQ } \\
\hline Event & $\begin{array}{c}\text { \% } \\
\text { Change } \\
\text { in STT }\end{array}$ & $\begin{array}{c}\text { \# of } \\
\text { firms }\end{array}$ & Price & $\begin{array}{c}\text { Market } \\
\text { value }\end{array}$ & $\sigma$ & $\begin{array}{c}\text { \# of } \\
\text { firms }\end{array}$ & Price & $\begin{array}{c}\text { Market } \\
\text { value }\end{array}$ & $\sigma$ \\
\hline $\begin{array}{c}\text { March 1, 1932 STT } \\
\text { doubled }\end{array}$ & $0.02 \%$ & 236 & 19.6 & 102.0 & 0.033 & & & & \\
\hline $\begin{array}{c}\text { June 2, 1933 } \\
\text { changed to per } \\
\text { share }\end{array}$ & $0.58 \%$ & 238 & 26.0 & 126.6 & 0.060 & & & & \\
\hline $\begin{array}{c}\text { 1945 reduced for } \\
\text { stocks less than } \\
\mathbf{\$ 1 0}\end{array}$ & $-0.40 \%$ & 526 & 32.7 & 79.6 & 0.010 & & & & \\
\hline $\begin{array}{c}\text { July 1966: 25\% } \\
\text { increase }\end{array}$ & $0.10 \%$ & 1,704 & 28.3 & 286.8 & 0.009 & & & & \\
\hline $\begin{array}{c}\text { August 1975: 25\% } \\
\text { increase }\end{array}$ & $0.13 \%$ & 1,912 & 17.4 & 326.9 & 0.010 & 1,721 & 11.1 & 281.4 & 0.009 \\
\hline $\begin{array}{c}\text { August 1978: 25\% } \\
\text { decrease }\end{array}$ & $-0.16 \%$ & 1,646 & 22.2 & 489.0 & 0.011 & 1,540 & 17.3 & 401.0 & 0.008 \\
\hline $\begin{array}{c}\text { October 1979: 30\% } \\
\text { rebate }\end{array}$ & $-0.14 \%$ & 1,742 & 22.6 & 518.4 & 0.012 & 1,658 & 16.7 & 477.3 & 0.009 \\
\hline $\begin{array}{c}\text { October 1980: 60\% } \\
\text { rebate }\end{array}$ & $-0.20 \%$ & 1,802 & 24.0 & 583.0 & 0.010 & 1,628 & 18.3 & 503.0 & 0.007 \\
\hline $\begin{array}{c}\text { October 1981: } \\
\text { 100\% rebate }\end{array}$ & $-0.40 \%$ & 1,702 & 19.9 & 546.3 & 0.011 & 1,545 & 16.7 & 468.4 & 0.008 \\
\hline
\end{tabular}




\section{Table 3 \\ Portfolio Volatility}

This table measures changes in volatility following nine changes in the New York State Stock Transfer Tax over the period 1932 to 1981 (when the tax was abolished.) Sample stocks are all those continuously traded on the on the two New York stock exchanges - the NYSE and AMEX one year pre- and one year post- each tax change. There are four exceptions to this due to the proximity of confounding events. For the March 1932 increase, twelve months pre are used and eleven months post (June 1932 to May 1933) are used to combine the New York STT doubling with the Federal STT doubling and to control for the New York STT change from par values to per share. For the July 1966 New York state tax increase, six months pre and post are used to avoid the January 1966 elimination of the federal security transaction tax. Similarly, fixed commissions were abolished three months prior to the August 1975 STT increase. Therefore the 1975 event uses three months pre and post. Finally, between April and November regional exchanges join the Intermarket Trading system which gives them a rebate on the tax for orders placed through them to New York. Accordingly we define the post period as December 1978 through June 1979. For each event we list the percentage change in the security transaction tax for a stock with a market price of $\$ 5$.

We define volatility as the standard deviation of daily returns for the period before $\left(\sigma_{\text {pre }}\right)$ and the period after $\left(\sigma_{\text {post }}\right)$ and specify the change in volatility as $\Delta \sigma=\sigma_{\text {post }}-\sigma_{\text {pre }}$. The standard deviation of portfolio $p$ is defined as $\sqrt{\pi / 2}\left|R_{p t}\right|$, where $R_{p t}$ is the daily equally weighted portfolio and $\pi$ is the mathematical constant 3.14. In Panel A we regress the standard deviation of each portfolio on a dummy variable which takes the value 0 pre-event and 1 post-event, yields changes in volatility. We thus use the following time-series regression to estimate volatility pre- and postevent

$$
\sqrt{\pi / 2}\left|R_{p t}\right|=\beta_{p 0}+\beta_{p 1} I_{P O S T, t}+\varepsilon_{p t},
$$

where $R_{p t}$ is the daily equally weighted portfolio and $I_{P O S T, t}$ is a dummy variable which takes the value 1 for the post-event period and 0 for the time period prior to the event. Newey-West standard errors are reported in parentheses below each parameter. For tax changes starting in 1975 NASDAQ stocks are used as a control for market wide changes in volatility. The last column in Panel A provides results of a Wald test for the equivalency of $\beta_{\mathrm{p} 1}$ between the two samples.

Panel B report the results of the following time-series regression analysis of NYSE/AMEX portfolio volatility proportional to NASDAQ volatility:

$$
\sigma_{p t}^{N Y}=\gamma_{0}+\gamma_{1} \hat{\sigma}_{p t}^{N A S D}+\gamma_{2} \hat{\sigma}_{p t}^{N A S D} I_{p o s t, t}+\varepsilon_{p t}
$$

where $\sigma_{p t}^{N Y}$ is the standard deviation of a NYSE portfolio $p$ at time $t$ estimated as the absolute value of the return to the portfolio multiplied by $\sqrt{\pi / 2} ; I_{P O S T, t}$ is a dummy variable, taking on the value 0 for the pre-event period and 1 for the post even time frame; $\hat{\sigma}_{p t}^{N A S D}$ is the estimated standard deviation of returns on the size-relevant NASDAQ portfolio at time $t$. That is,

$$
\beta_{0}+\sum_{i=1}^{12} \beta_{i} \sigma_{p t-i}^{N A S D}+\mu_{p t}
$$

where $\sigma_{p t}^{N A S D}$ is the daily portfolio return standard deviation of the NASDAQ sample regressed on its 12 lags. Newey-West standard errors are reported in parentheses.

\section{Table on next page}

\section{Table 3}


Portfolio Volatility

(continued)

\begin{tabular}{|c|c|c|c|c|c|c|}
\hline \multicolumn{7}{|c|}{ Panel A. Portfolio Volatility Pre- and Post- Event } \\
\hline \multirow[b]{2}{*}{$\begin{array}{l}\text { Date and } \\
\text { Event }\end{array}$} & \multicolumn{3}{|c|}{ NYSE and AMEX Stocks } & \multicolumn{2}{|c|}{ NASDAQ Stocks } & \multirow[b]{2}{*}{$\begin{array}{l}\text { Wald test p-value } \\
\text { Ho: } \beta_{p 1}^{N Y S E}=\beta_{p 1}^{N A S D A Q}\end{array}$} \\
\hline & $\begin{array}{c}\% \\
\text { Change } \\
\text { in STT }\end{array}$ & $\begin{array}{c}\beta_{p 0} \\
\text { (pre- } \\
\text { event) }\end{array}$ & $\begin{array}{c}\beta_{p 1} \\
\text { (change) }\end{array}$ & $\begin{array}{c}\beta_{p 0} \\
\text { (pre-event) }\end{array}$ & $\begin{array}{c}\beta_{p 1} \\
\text { (change) }\end{array}$ & \\
\hline $\begin{array}{c}\text { March 1, } \\
1932 \text { STT } \\
\text { doubled }\end{array}$ & $0.02 \%$ & 0.033 & $\begin{array}{c}0.006 \\
\left(1.98^{*}\right)\end{array}$ & & & \\
\hline $\begin{array}{c}\text { June 2, } 1933 \\
\text { changed to } \\
\text { per share }\end{array}$ & $0.58 \%$ & 0.060 & $\begin{array}{c}0.009 \\
\left(2.77^{* * *}\right)\end{array}$ & & & \\
\hline $\begin{array}{c}1945 \\
\text { reduced for } \\
\text { stocks less } \\
\text { than } \$ 10\end{array}$ & $-0.40 \%$ & 0.010 & $\begin{array}{c}0.002 \\
\left(2.76^{* * *}\right)\end{array}$ & & & \\
\hline $\begin{array}{c}\text { July 1966: } \\
25 \% \\
\text { increase }\end{array}$ & $0.10 \%$ & 0.009 & $\begin{array}{l}0.001 \\
(0.78)\end{array}$ & & & \\
\hline $\begin{array}{l}\text { August } \\
\text { 1975: } 25 \% \\
\text { increase }\end{array}$ & $0.13 \%$ & 0.010 & $\begin{array}{c}-0.003 \\
\left(-3.03^{\star * *}\right) \\
\end{array}$ & 0.009 & $\begin{array}{l}-0.002 \\
\left(-2.5^{* *}\right) \\
\end{array}$ & 0.62 \\
\hline $\begin{array}{c}\text { August } \\
\text { 1978: } 25 \% \\
\text { decrease }\end{array}$ & $-0.16 \%$ & 0.011 & $\begin{array}{l}0.002 \\
(1.49)\end{array}$ & 0.008 & $\begin{array}{c}0.002 \\
\left(1.86^{*}\right) \\
\end{array}$ & 0.54 \\
\hline $\begin{array}{l}\text { October } \\
\text { 1979: } 30 \% \\
\text { rebate }\end{array}$ & $-0.14 \%$ & 0.012 & $\begin{array}{l}0.002 \\
(1.40)\end{array}$ & 0.009 & $\begin{array}{c}0.002 \\
\left(1.71^{*}\right)\end{array}$ & 0.81 \\
\hline $\begin{array}{c}\text { October } \\
1980: 60 \% \\
\text { rebate }\end{array}$ & $-0.20 \%$ & 0.010 & $\begin{array}{l}-0.001 \\
(-1.29) \\
\end{array}$ & 0.007 & $\begin{array}{c}-0.001 \\
(-1.5)\end{array}$ & 0.87 \\
\hline $\begin{array}{l}\text { October } \\
\text { 1981: } 100 \% \\
\text { rebate }\end{array}$ & $-0.40 \%$ & 0.011 & $\begin{array}{l}-0.001 \\
(1.21)\end{array}$ & 0.008 & $\begin{array}{l}-0.001 \\
\left(1.93^{*}\right)\end{array}$ & 0.85 \\
\hline
\end{tabular}


Table 3

Portfolio Volatility

(continued)

\begin{tabular}{|c|c|c|c|c|c|}
\hline \multicolumn{6}{|c|}{ Panel B. Time-Series Regression Analysis of Portfolio Volatility } \\
\hline $\begin{array}{l}\text { Date and } \\
\text { Event }\end{array}$ & $\begin{array}{c}\% \text { Change in } \\
\text { STT }\end{array}$ & $\gamma_{0}$ & $\gamma_{1}$ & $\gamma_{2}$ & $\bar{R}^{2}$ \\
\hline $\begin{array}{c}\text { August } \\
\text { 1975: } 25 \% \\
\text { increase }\end{array}$ & $0.13 \%$ & $\begin{array}{l}0.0050 \\
(0.002)\end{array}$ & $\begin{array}{c}1.022 \\
(0.214)\end{array}$ & $\begin{array}{c}0.029 \\
(0.058)\end{array}$ & 0.13 \\
\hline $\begin{array}{c}\text { August } \\
\text { 1978: } 25 \% \\
\text { decrease }\end{array}$ & $-0.16 \%$ & $\begin{array}{l}0.0032 \\
(0.004)\end{array}$ & $\begin{array}{c}0.912 \\
(0.105)\end{array}$ & $\begin{array}{c}0.125 \\
(0.108)\end{array}$ & 0.24 \\
\hline $\begin{array}{c}\text { October } \\
\text { 1979: } 30 \% \\
\text { rebate }\end{array}$ & $-0.14 \%$ & $\begin{array}{l}0.0012 \\
(0.004)\end{array}$ & $\begin{array}{c}0.927 \\
(0.077)\end{array}$ & $\begin{array}{c}-0.076 \\
\left(0.032^{* *}\right)\end{array}$ & 0.22 \\
\hline $\begin{array}{c}\text { October } \\
\text { 1980: } 60 \% \\
\text { rebate }\end{array}$ & $-0.20 \%$ & $\begin{array}{l}0.0021 \\
(0.003)\end{array}$ & $\begin{array}{c}1.013 \\
(0.086)\end{array}$ & $\begin{array}{l}-0.091 \\
(0.059)\end{array}$ & 0.16 \\
\hline $\begin{array}{c}\text { October } \\
\text { 1981: } 100 \% \\
\text { rebate }\end{array}$ & $-0.40 \%$ & $\begin{array}{l}0.0013 \\
(0.004)\end{array}$ & $\begin{array}{c}1.024 \\
(0.087)\end{array}$ & $\begin{array}{l}-0.096 \\
(0.064)\end{array}$ & 0.08 \\
\hline
\end{tabular}

Denote significant at the $0.01,0.05$ and the 0.10 level respectively. 


\section{Table 4 \\ Spread Width}

This table measures changes in spread width following nine changes in the New York State Stock Transfer Tax over the period 1932 to 1981 (when the tax was abolished.) Sample stocks are all those continuously traded on the on the two New York stock exchanges - the NYSE and AMEX one year pre- and one year post- each tax change. There are four exceptions to this due to the proximity of confounding events. For the March 1932 increase, twelve months pre are used and eleven months post (June 1932 to May 1933) are used to combine the New York STT doubling with the Federal STT doubling and to control for the New York STT change from par values to per share. For the July 1966 New York state tax increase, six months pre and post are used to avoid the January 1966 elimination of the federal security transaction tax. Similarly, fixed commissions were abolished three months prior to the August 1975 STT increase. Therefore the 1975 event uses three months pre and post. Finally, between April and November regional exchanges join the Intermarket Trading system which gives them a rebate on the tax for orders placed through them to New York. Accordingly we define the post period as December 1978 through June 1979. For each event we list the percentage change in the security transaction tax for a stock with a market price of $\$ 5$.

We define spread as the low frequency measure described in Appendix $B$ and here referred to as Holden. Panel A lists the results of univariate tests for changes in spread, while Panel B lists the results of the control regression

$$
\text { Holden }_{i, t}=\beta_{0}+\beta_{1} \text { Vol }_{i, t}+\beta_{2} \sigma_{i, t}+\beta_{3} \text { Dummy }_{i, t}+\varepsilon_{i, t}
$$

where $\mathrm{Vol}$ is traded volume for stock $i$ on day $t, \sigma$ is the standard deviation of daily returns, and Dummy takes the value 0 pre-event and 1 post event. The parameter estimate is followed by the Newey-West Autocorrelation consistent t-statistic. R-squares are also reported for each event.

\begin{tabular}{|c|c|c|c|c|c|}
\hline \multicolumn{6}{|c|}{ Panel A. Univariate Statistics } \\
\hline Event & $\begin{array}{c}\% \\
\text { Change } \\
\text { in STT }\end{array}$ & Spread $_{\text {pre }}$ & Spread $_{\text {post }}$ & $\Delta$ Spread & $\mathbf{t}$ \\
\hline $\begin{array}{c}\text { March 1, } 1932 \text { STT } \\
\text { doubled }\end{array}$ & $0.02 \%$ & 1.63 & 3.01 & 1.38 & $4.9^{* \star *}$ \\
\hline $\begin{array}{c}\text { June 2, } 1933 \\
\text { changed to per } \\
\text { share }\end{array}$ & $0.58 \%$ & 1.75 & 3.48 & 1.73 & $6.2^{* * *}$ \\
\hline $\begin{array}{c}1945 \text { reduced for } \\
\text { stocks less than } \\
\$ 10\end{array}$ & $-0.40 \%$ & 1.16 & 0.85 & -0.31 & $-2.30^{* *}$ \\
\hline $\begin{array}{c}\text { July 1966: } 25 \% \\
\text { increase }\end{array}$ & $0.10 \%$ & 1.19 & 1.49 & 0.3 & $2.00^{* *}$ \\
\hline $\begin{array}{c}\text { August 1975: } 25 \% \\
\text { increase }\end{array}$ & $0.13 \%$ & 2.20 & 2.31 & 0.1 & $1.70^{*}$ \\
\hline $\begin{array}{c}\text { August 1978: } 25 \% \\
\text { decrease }\end{array}$ & $-0.16 \%$ & 1.49 & 1.42 & -0.07 & $-2.50^{* * *}$ \\
\hline $\begin{array}{l}\text { October 1979: } 30 \% \\
\text { rebate }\end{array}$ & $-0.14 \%$ & 1.29 & 1.26 & -0.03 & -0.17 \\
\hline $\begin{array}{l}\text { October 1980: } 60 \% \\
\text { rebate }\end{array}$ & $-0.20 \%$ & 1.26 & 1.09 & -0.16 & $-2.50^{* * *}$ \\
\hline $\begin{array}{c}\text { October 1981: } \\
100 \% \text { rebate }\end{array}$ & $-0.40 \%$ & 1.11 & 1.33 & -0.22 & $-4.30^{* * *}$ \\
\hline
\end{tabular}


Table 4

Spread Width

(continued)

\begin{tabular}{|c|c|c|c|c|c|c|}
\hline \multicolumn{7}{|c|}{ Panel B. Control Regressions } \\
\hline Event & $\begin{array}{c}\% \text { Change } \\
\text { in STT }\end{array}$ & Intercept & Volume & $\sigma$ & Dummy & $\begin{array}{l}\text { Adjusted R- } \\
\text { squared }\end{array}$ \\
\hline $\begin{array}{c}\text { March 1, } \\
1932 \text { STT } \\
\text { doubled }\end{array}$ & $0.02 \%$ & $\begin{array}{l}5.2 \\
21.2^{* * *}\end{array}$ & $\begin{array}{c}-2 E-4 \\
-10.1^{* * *}\end{array}$ & $\begin{array}{c}7.1 \\
3.2^{* \star \star}\end{array}$ & $\begin{array}{c}0.48 \\
2.11^{* *}\end{array}$ & 0.39 \\
\hline $\begin{array}{c}\text { June } 2, \\
1933 \\
\text { changed to } \\
\text { per share }\end{array}$ & $0.58 \%$ & $\begin{array}{c}3.1 \\
9.8^{* * *}\end{array}$ & $\begin{array}{l}-2 E-4 \\
-5.7^{\star * *}\end{array}$ & $\begin{array}{c}9.8 \\
4.0^{* * *}\end{array}$ & $\begin{array}{l}0.61 \\
2.2^{* *}\end{array}$ & 0.45 \\
\hline $\begin{array}{c}1945 \\
\text { reduced for } \\
\text { stocks less } \\
\text { than } \$ 10\end{array}$ & $-0.40 \%$ & $\begin{array}{c}2.5 \\
22.8^{* * *}\end{array}$ & $\begin{array}{l}6 \mathrm{E}-5 \\
5.1^{* * *}\end{array}$ & $\begin{array}{l}-0.87 \\
-0.09\end{array}$ & $\begin{array}{l}-0.22 \\
-2.7^{* * *}\end{array}$ & 0.53 \\
\hline $\begin{array}{c}\text { July 1966: } \\
25 \% \\
\text { increase } \\
\end{array}$ & $0.10 \%$ & $\begin{array}{c}2.2 \\
16.8^{\star * *}\end{array}$ & $\begin{array}{l}-2 E-4 \\
-7.1^{* * *}\end{array}$ & $\begin{array}{l}-5.77 \\
-1.2\end{array}$ & $\begin{array}{l}0.25 \\
2.1^{\text {** }}\end{array}$ & 0.50 \\
\hline $\begin{array}{c}\text { August } \\
\text { 1975: } 25 \% \\
\text { increase }\end{array}$ & $0.13 \%$ & $\begin{array}{c}3.8 \\
14.2^{* \star *}\end{array}$ & $\begin{array}{c}-1.2 E-4 \\
-6.0 * * *\end{array}$ & $\begin{array}{l}15.4 \\
1.6^{*}\end{array}$ & $\begin{array}{c}0.28 \\
3.0^{\star \star \star}\end{array}$ & 0.51 \\
\hline $\begin{array}{c}\text { August } \\
\text { 1978: } 25 \% \\
\text { decrease }\end{array}$ & $-0.16 \%$ & $\begin{array}{c}2.7 \\
21.0^{\star * *}\end{array}$ & $\begin{array}{l}-9 E-6 \\
-2.9^{* * *}\end{array}$ & $\begin{array}{c}9.8 \\
2.5^{\star \star \star}\end{array}$ & $\begin{array}{l}-0.44 \\
-2.0^{* *} \\
\end{array}$ & 0.62 \\
\hline $\begin{array}{c}\text { October } \\
\text { 1979: } 30 \% \\
\text { rebate }\end{array}$ & $-0.14 \%$ & $\begin{array}{c}2.3 \\
28.9^{* * *}\end{array}$ & $\begin{array}{l}-5 E-6 \\
-2.4^{* * *}\end{array}$ & $\begin{array}{c}4.2 \\
2.1^{\star *}\end{array}$ & $\begin{array}{c}0.09 \\
1.5\end{array}$ & 0.56 \\
\hline $\begin{array}{c}\text { October } \\
\text { 1980: } 60 \% \\
\text { rebate }\end{array}$ & $-0.20 \%$ & $\begin{array}{c}2.3 \\
28.4^{* * *}\end{array}$ & $\begin{array}{l}7 E-6 \\
2.3^{* *}\end{array}$ & $\begin{array}{l}2.5 \\
1.6\end{array}$ & $\begin{array}{l}-0.07 \\
-1.2\end{array}$ & 0.57 \\
\hline $\begin{array}{c}\text { October } \\
\text { 1981: } 100 \% \\
\text { rebate }\end{array}$ & $-0.40 \%$ & $\begin{array}{c}2.4 \\
32.7^{* * *}\end{array}$ & $\begin{array}{l}-3 E-6 \\
-1.4\end{array}$ & $\begin{array}{l}2.7 \\
1.8\end{array}$ & $\begin{array}{c}-0.06 \\
-0.7\end{array}$ & 0.63 \\
\hline
\end{tabular}

${ }^{* * *},{ }^{* * *}$ Denote significant at the $0.01,0.05$ and the 0.10 level respectively. 


\section{Table 5}

\section{Market Share and Volume}

This table measures changes in market share and volume for US stock markets following nine changes in the New York State Stock Transfer Tax over the period 1932 to 1981 (when the tax was abolished.) Volume is defined as the average monthly volume over the period. Market share for exchange $j$ for month $t$ is then defined as

$$
\text { marketshare }_{x, t}=\frac{\text { volume }_{x, t}}{\sum_{x=1}^{n} \text { volume }_{x, t}}
$$

Exchanges examined are the NYSE and the regional exchanges in existence at the time of the STT change. Data are averaged one year pre- and one year post- each tax change. There are four exceptions to this due to the proximity of confounding events. For the March 1932 increase, twelve months pre are used and eleven months post (June 1932 to May 1933) are used to combine the New York STT doubling with the Federal STT doubling and to control for the New York STT change from par values to per share. For the July 1966 New York state tax increase, six months pre and post are used to avoid the January 1966 elimination of the federal security transaction tax. Similarly, fixed commissions were abolished three months prior to the August 1975 STT increase. Therefore the 1975 event uses three months pre and post. Finally, between April and November regional exchanges join the Intermarket Trading system which gives them a rebate on the tax for orders placed through them to New York. Accordingly we define the post period as December 1978 through June 1979. For each event we list the percentage change in the security transaction tax for a stock with a market price of $\$ 5$. Listed are the pre and post event market share and volume per exchange as well as the t-statistic for the post-pre difference.

(table on next page) 
Table 5

Market Share and Volume

(continued)

\begin{tabular}{|c|c|c|c|c|c|c|}
\hline \multirow[b]{2}{*}{ Exchange } & \multicolumn{3}{|c|}{ Market share } & \multicolumn{3}{|c|}{ Volume } \\
\hline & $\begin{array}{l}\text { Pre- } \\
\text { event }\end{array}$ & $\begin{array}{l}\text { Post- } \\
\text { event }\end{array}$ & t-stat & Pre-event & Post-event & t-stat \\
\hline \multicolumn{7}{|c|}{ Panel A - March 1, 1932 STT doubled 0.02\% increase in STT } \\
\hline NYSE & $88.5 \%$ & $92.2 \%$ & $3.2^{* *}$ & $44,684,316$ & $57,546,326$ & 1.6 \\
\hline Chicago & $4.9 \%$ & $2.2 \%$ & $-6.6^{* * *}$ & $2,500,417$ & 952,625 & $-4.4^{\star * *}$ \\
\hline Philly & $1.6 \%$ & $1.2 \%$ & -1.83 & 811,830 & 508,993 & $-2.4^{* *}$ \\
\hline L.A. & $0.8 \%$ & $0.5 \%$ & $-2.56^{* *}$ & 399,172 & 215,719 & $-3.05^{* * *}$ \\
\hline Boston & $1.4 \%$ & $1.5 \%$ & 0.5 & 673,552 & 623,022 & -0.40 \\
\hline Baltimore & $0.1 \%$ & $0.1 \%$ & -0.38 & 40,580 & 33,528 & -0.83 \\
\hline Pittsburgh & $0.3 \%$ & $0.4 \%$ & 1.35 & 128,954 & 140,868 & 0.3 \\
\hline Cleveland & $0.1 \%$ & $0.1 \%$ & 0.3 & 39,981 & 32,532 & -1.20 \\
\hline San Fran. & $1.8 \%$ & $1.3 \%$ & -1.67 & 879,002 & 551.673 & $-2.22^{* *}$ \\
\hline Detroit & $0.6 \%$ & $0.5 \%$ & -1.16 & 299,416 & 209,207 & -1.70 \\
\hline \multicolumn{7}{|c|}{ Panel B - June 2, 1933 changed to per share $0.58 \%$ increase in STT } \\
\hline NYSE & $92.6 \%$ & $89.5 \%$ & $-2.3^{* *}$ & $53,527,339$ & $36,310,664$ & -1.77 \\
\hline Chicago & $1.9 \%$ & $2.5 \%$ & 1.1 & 833,667 & $1,193,333$ & 1.54 \\
\hline Philly & $1.2 \%$ & $2.8 \%$ & 1.29 & 474,950 & $1,560,784$ & 1.41 \\
\hline L.A. & $0.5 \%$ & $0.5 \%$ & -0.31 & 201,480 & 298,840 & $1.98^{*}$ \\
\hline Boston & $1.4 \%$ & $1.3 \%$ & -0.40 & 559,110 & 556,060 & -0.2 \\
\hline Baltimore & $0.1 \%$ & $0.1 \%$ & -1.25 & 34,673 & 77,721 & $2.02^{*}$ \\
\hline Pittsburgh & $0.3 \%$ & $0.5 \%$ & 1.28 & 126,294 & 219,166 & $2.1^{*}$ \\
\hline Cleveland & $0.9 \%$ & $0.2 \%$ & $-2.34^{* *}$ & 33,594 & 94,990 & $3.51^{* * *}$ \\
\hline San Fran. & $1.2 \%$ & $1.9 \%$ & 1.64 & 493,948 & 929,328 & $2.97^{* * *}$ \\
\hline Detroit & $0.5 \%$ & $0.6 \%$ & 0.36 & 340,508 & 285,598 & $-0.64^{* *}$ \\
\hline
\end{tabular}


Table 5

Market Share and Volume

(continued)

\begin{tabular}{|c|c|c|c|c|c|c|}
\hline \multirow[b]{2}{*}{ Exchange } & \multicolumn{3}{|c|}{ Market Share } & \multicolumn{3}{|c|}{ Volume } \\
\hline & $\begin{array}{l}\text { Pre- } \\
\text { event }\end{array}$ & $\begin{array}{l}\text { Post- } \\
\text { event }\end{array}$ & t-stat & Pre-event & Post-event & t-stat \\
\hline \multicolumn{7}{|c|}{ Panel C - 1945 reduced for stocks less than $\$ 10$ 0.40\% decrease for a $\$ 5$ stock } \\
\hline NYSE & $89.9 \%$ & $91.7 \%$ & $6.85^{\star * \star}$ & $31,357,139$ & $39,191,840$ & $15.60^{* * *}$ \\
\hline Chicago & $2.4 \%$ & $2.2 \%$ & -1.65 & 833,666 & 935,333 & 1.90 \\
\hline Philly & $1.3 \%$ & $0.9 \%$ & $-4.06^{* * *}$ & 479,070 & 391,742 & $-2.88^{* *}$ \\
\hline L.A. & $1.5 \%$ & $1.3 \%$ & -1.83 & 530,851 & 568,162 & 0.90 \\
\hline Boston & $1.5 \%$ & $1.0 \%$ & $-5.6^{* * *}$ & 530,478 & 425,707 & $-3.33^{* * *}$ \\
\hline Baltimore & $0.1 \%$ & $0.1 \%$ & 1.12 & 24,778 & 36,422 & $7.80^{* * *}$ \\
\hline Pittsburgh & $0.2 \%$ & $0.2 \%$ & $-6.8^{* * *}$ & 84,681 & 77,843 & -0.04 \\
\hline Cleveland & $0.1 \%$ & $0.1 \%$ & 1.75 & 46,095 & 44,436 & -0.38 \\
\hline San Fran. & $1.6 \%$ & $1.4 \%$ & 1.64 & 569,306 & 588,901 & 1.07 \\
\hline Detroit & $1.2 \%$ & $1.0 \%$ & $-2.47^{* *}$ & 425,291 & 451,383 & 1.27 \\
\hline \multicolumn{7}{|c|}{ Panel D - July 1966: $25 \%$ increase in STT 0.10\% increase for a $\$ 5$ stock } \\
\hline NYSE & $90.2 \%$ & $88.8 \%$ & $-3.50^{* * *}$ & $173,174,234$ & $143,574,934$ & $-1.97^{*}$ \\
\hline Midwest & $3.9 \%$ & $4.1 \%$ & 0.97 & $7,533,833$ & $6,705,833$ & -1.00 \\
\hline Philly & $1.2 \%$ & $1.6 \%$ & $3.51^{* * *}$ & $2,223,535$ & $2,529,249$ & $2.08^{*}$ \\
\hline Pacific & $3.9 \%$ & $4.6 \%$ & $2.32^{* *}$ & $7,508,775$ & $7,313,173$ & -0.44 \\
\hline Boston & $0.6 \%$ & $0.7 \%$ & $2.47^{* *}$ & $1,091,162$ & $1,137,909$ & 0.76 \\
\hline Pittsburgh & $0.1 \%$ & $0.1 \%$ & -0.92 & 110,783 & 85,183 & -1.58 \\
\hline Detroit & $0.2 \%$ & $0.2 \%$ & 0.69 & 338,685 & 299,694 & -0.78 \\
\hline \multicolumn{7}{|c|}{ Panel E - August 1975: 25\% increase in STT 0.13\% increase for a $\$ 5$ stock } \\
\hline NYSE & $89.0 \%$ & $87.9 \%$ & $-8.95^{* * *}$ & $448,721,396$ & $307,361,199$ & $-4.33^{* * *}$ \\
\hline Midwest & $4.4 \%$ & $4.8 \%$ & $3.32^{* *}$ & $22,025,000$ & $16,655,000$ & $-4.33^{* * *}$ \\
\hline Philly & $1.7 \%$ & $2.0 \%$ & $3.82^{* \star \star}$ & $8,613,179$ & $6,831,777$ & $-2.05^{*}$ \\
\hline Pacific & $4.0 \%$ & $4.4 \%$ & $2.86^{* *}$ & $20,017,213$ & $15,522,371$ & -1.75 \\
\hline Boston & $1.0 \%$ & $1.0 \%$ & -0.65 & $4,959,876$ & $3,333,667$ & $-3.65^{* * *}$ \\
\hline \multicolumn{7}{|c|}{ Panel F - August 1978: $25 \%$ decrease in STT 0.16\% decrease for a $\$ 5$ stock } \\
\hline NYSE & $88.4 \%$ & $89.1 \%$ & 1.54 & $492,256,231$ & $596,529,544$ & $1.98^{*}$ \\
\hline Midwest & $4.8 \%$ & $3.9 \%$ & $-5.34^{* \star *}$ & $26,265,233$ & $28,028,860$ & 1.0 \\
\hline Philly & $2.2 \%$ & $2.6 \%$ & 1.84 & $12,515,964$ & $18,835,620$ & $5.77^{* * *}$ \\
\hline Pacific & $3.9 \%$ & $3.7 \%$ & -1.17 & $22,498,255$ & $27,350,599$ & $2.27^{* *}$ \\
\hline Boston & $0.7 \%$ & $0.7 \%$ & -0.44 & $4,337,420$ & $5,289,851$ & $2.16^{\star}$ \\
\hline
\end{tabular}


Table 5

Market Share and Volume

(continued)

\begin{tabular}{|c|c|c|c|c|c|c|}
\hline \multirow[b]{2}{*}{ Exchange } & \multicolumn{3}{|c|}{ Market Share } & \multicolumn{3}{|c|}{ Volume } \\
\hline & $\begin{array}{l}\text { Pre- } \\
\text { event }\end{array}$ & $\begin{array}{l}\text { Post- } \\
\text { event }\end{array}$ & t-stat & Pre-event & Post-event & t-stat \\
\hline \multicolumn{7}{|c|}{ Panel G - October 1979: $30 \%$ rebate a $0.14 \%$ decrease for a $\$ 5$ stock } \\
\hline NYSE & $89.0 \%$ & $88.5 \%$ & $-2.00^{*}$ & $651,084,936$ & $877,307,085$ & $4.7^{* * *}$ \\
\hline Midwest & $3.9 \%$ & $4.4 \%$ & $2.99^{* *}$ & $28,811,167$ & $43,749,917$ & $6.8^{* * *}$ \\
\hline Philly & $2.6 \%$ & $2.9 \%$ & $1.93^{*}$ & $19,110,916$ & $28,063,150$ & $6.7^{* * *}$ \\
\hline Pacific & $3.8 \%$ & $3.6 \%$ & -1.25 & $27,603,845$ & $35,440,801$ & $3.1^{* *}$ \\
\hline Boston & $0.7 \%$ & $0.7 \%$ & -0.81 & $5,070,833$ & $6,652,500$ & $3.35^{\star * *}$ \\
\hline \multicolumn{7}{|c|}{ Panel H - October 1980: $60 \%$ rebate a $0.20 \%$ decrease for a $\$ 5$ stock } \\
\hline NYSE & $88.5 \%$ & $88.2 \%$ & -1.07 & $877,307,085$ & $996,396,401$ & 1.8 \\
\hline Midwest & $4.4 \%$ & $4.9 \%$ & $2.79^{* *}$ & $43,749,917$ & $55,343,917$ & $3.4^{* * *}$ \\
\hline Philly & $2.9 \%$ & $2.8 \%$ & -0.31 & $28,063,150$ & $31,858,280$ & $3.6^{* \star *}$ \\
\hline Pacific & $3.6 \%$ & $3.4 \%$ & -1.50 & $35,440,801$ & $38,225,695$ & 1.02 \\
\hline Boston & $0.7 \%$ & $0.6 \%$ & -1.46 & $6,652,500$ & $7,192,333$ & 0.92 \\
\hline \multicolumn{7}{|c|}{ Panel I - October 1981: $100 \%$ rebate a $0.40 \%$ decrease for a $\$ 5$ stock } \\
\hline NYSE & $88.2 \%$ & $87.4 \%$ & $-4.14^{\star * *}$ & $996,396,401$ & $1,149,472,970$ & $2.06^{*}$ \\
\hline Midwest & $4.9 \%$ & $5.7 \%$ & $6.04^{* * *}$ & $55,343,917$ & $75,550,417$ & $4.24^{* * *}$ \\
\hline Philly & $2.8 \%$ & $2.8 \%$ & 0.11 & $31,858,280$ & $37,151,226$ & $2.67^{* *}$ \\
\hline Pacific & $3.4 \%$ & $3.5 \%$ & 0.96 & $38,225,695$ & $46,700,845$ & 2.2 \\
\hline Boston & $0.6 \%$ & $0.6 \%$ & $-3.41^{\star \star \star}$ & $7,192,333$ & $7,445,000$ & 0.5 \\
\hline
\end{tabular}

\footnotetext{
${ }^{* * *},{ }^{* * *},{ }^{*}$ Denote significant at the $0.01,0.05$ and the 0.10 level respectively.
} 
Table 6

\section{Amihud Illiquidity Measure}

This table measures changes the Amihud illiquidity measure following nine changes in the New York State Stock Transfer Tax over the period 1932 to 1981 (when the tax was abolished.) Sample stocks are all those continuously traded on the on the two New York stock exchanges the NYSE and AMEX one year pre- and one year post- each tax change. There are four exceptions to this due to the proximity of confounding events. For the March 1932 increase, twelve months pre are used and eleven months post (June 1932 to May 1933) are used to combine the New York STT doubling with the Federal STT doubling and to control for the New York STT change from par values to per share. For the July 1966 New York state tax increase, six months pre and post are used to avoid the January 1966 elimination of the federal security transaction tax. Similarly, fixed commissions were abolished three months prior to the August 1975 STT increase. Therefore the 1975 event uses three months pre and post. Finally, between April and November regional exchanges join the Intermarket Trading system which gives them a rebate on the tax for orders placed through them to New York. Accordingly we define the post period as December 1978 through June 1979. For each event we list the percentage change in the security transaction tax for a stock with a market price of $\$ 5$. The illiquidity measure, Amihud, is defined as

$$
\text { Amihud }=\frac{\left|r_{i, t}\right|}{\$ \text { Volume }}
$$

Where $r_{i t}$ and $\$$ Volume $_{i, t}$ are the stock return and dollar volume for stock $i$ on day $t$, respectively. Listed are the results of univariate tests for changes in the measure.

\begin{tabular}{|c|c|c|c|c|c|}
\hline Event & \begin{tabular}{|c|}
$\%$ \\
Change \\
in STT \\
\end{tabular} & Amihud $_{\text {pre }}$ & Amihud $_{\text {post }}$ & $\Delta$ Amihud & $t$ \\
\hline $\begin{array}{c}\text { March 1, } 1932 \text { STT } \\
\text { doubled) }\end{array}$ & $0.02 \%$ & $2.6 \mathrm{E}-10$ & $4.9 \mathrm{E}-10$ & 2.3E-10 & $7.9 * * *$ \\
\hline $\begin{array}{l}\text { June 2, } 1933 \\
\text { changed to per } \\
\text { share }\end{array}$ & $0.58 \%$ & $.8 \mathrm{E}-10$ & 4.7E-10 & $1.9 \mathrm{E}-10$ & $6.97 * * *$ \\
\hline $\begin{array}{c}1945 \text { reduced for } \\
\text { stocks less than } \\
\$ 10\end{array}$ & $-0.40 \%$ & 4.1E-10 & 4.4E-10 & 3.5E-9 & 1.18 \\
\hline $\begin{array}{l}\text { July 1966: } 25 \% \\
\text { increase }\end{array}$ & $0.10 \%$ & $1.0 \mathrm{E}-10$ & $1.4 \mathrm{E}-10$ & 4.2E-9 & $3.18^{* * *}$ \\
\hline $\begin{array}{c}\text { August 1975: 25\% } \\
\text { increase }\end{array}$ & $0.13 \%$ & $1.0 \mathrm{E}-10$ & 7.4E-9 & $-2.7 \mathrm{E}-9$ & $-2.22^{* *}$ \\
\hline $\begin{array}{c}\text { August 1978: 25\% } \\
\text { decrease }\end{array}$ & $-0.16 \%$ & 1 & 10 & 10 & -1. \\
\hline $\begin{array}{c}\text { October 1979: } 30 \% \\
\text { rebate }\end{array}$ & $-0.14 \%$ & 1 & 1 & $-4.4 \mathrm{E}-10$ & $-1.74 *$ \\
\hline $\begin{array}{l}\text { October 1980: } 60 \% \\
\text { rebate }\end{array}$ & $-0.20 \%$ & 2.7E-11 & $2.0 \mathrm{E}-11$ & $-7.2 \mathrm{E}-10$ & $-3.75^{* * *}$ \\
\hline $\begin{array}{l}\text { October 1981: } \\
100 \% \text { rebate }\end{array}$ & $-0.40 \%$ & 2.1E-11 & $1.6 \mathrm{E}-11$ & $-4.3 \mathrm{E}-10$ & $-3.25^{* * *}$ \\
\hline
\end{tabular}

${ }^{* * *, * *, *}$ Denote significant at the $0.01,0.05$ and the 0.10 level respectively. 